\title{
Ligand-based molecular recognition and dioxygen splitting: an endo epoxide ending
}

Peter E. Sues, Matthew W. Forbes, Alan J. Lougha and Robert H. Morris

\author{
Version Post-print/accepted manuscript \\ Citation Sues, P. E., Forbes, M. W., Lough, A. J., \& Morris, R. H. (2014). \\ (published version) Ligand-based molecular recognition and dioxygen splitting: an endo \\ epoxide ending. Dalton Transactions, 43(10), 4137-4145. \\ Publisher's statement The final published version of this article is available from the Royal \\ Society of Chemistry at http://dx.doi.org/10.1039/C3DT53495B.
}

How to cite TSpace items

Always cite the published version, so the author(s) will receive recognition through services that track citation counts, e.g. Scopus. If you need to cite the page number of the author manuscript from TSpace because you cannot access the published version, then cite the TSpace version in addition to the published version using the permanent URI (handle) found on the record page.

This article was made openly accessible by $U$ of $T$ Faculty. Please tell us how this access benefits you. Your story matters. 


\title{
Ligand-based Molecular Recognition and Dioxygen Splitting: An Endo Epoxide Ending $\dagger$
}

\author{
Peter E. Sues ${ }^{a}$, Matthew W. Forbes ${ }^{a}$, Alan J. Lough ${ }^{a}$, and Robert H. Morris ${ }^{a^{*}}$ \\ The phosphido complex $\mathrm{RuCp}^{*}\left(\mathrm{PPh}_{2} \mathrm{CH}=\mathrm{CHPPh}\right)\left(\mathrm{PPh}_{2}\right)(1)$ was exposed to number of small molecules and was found to recognize \\ and activate molecular oxygen in an unprecedented fashion: the ruthenium species split $\mathrm{O}_{2}$ in a ligand-based 4-electron reduction to \\ produce an endo epoxide, as well as a phosphinito ligand. Based on XRD data, VT NMR studies, cyclooctene trapping studies, and \\ crossover experiments it was determined that the reaction proceeded through an intramolecular mechanism in which initial \\ oxidation of the phosphido ligand generated an end-on peroxo intermediate. This mechanism was also supported by computational \\ studies and electrochemical experiments. In contrast, an analogue of $1, \mathrm{RuCp}^{*}\left(\mathrm{Ph}_{2} \mathrm{P}\left(\right.\right.$ ortho- $\left.\left.\mathrm{C}_{6} \mathrm{H}_{4}\right) \mathrm{PPh}_{2}\right)\left(\mathrm{PPh}_{2}\right)(3), \mathrm{reacted}$ in an \\ intermolecular fashion to generate two phosphinito ligands.
}

\section{Introduction}

The direct use of molecular oxygen in chemical transformations, as a source of oxygen atoms, is an attractive prospect for synthetic and industrial chemists because it is an abundant, cheap and completely green reagent. The problem with using dioxygen, however, is that it is often difficult to activate without resorting to highly reducing species. ${ }^{[1,2]}$ In addition, once oxygen has been activated and partially reduced, the intermediate species are often more oxidising than $\mathrm{O}_{2}$ itself, and, thus, are extremely reactive. $[1,2]$ This can lead to uncontrolled reactions, and a lack of selectivity. ${ }^{[1,2]}$ It is therefore important to harness the oxidizing power of dioxygen in a measured and directed fashion in order to obtain a desired product.

Although difficult to control, there are some examples in the literature of using molecular oxygen directly as an oxygen source for epoxidation reactions. ${ }^{[2-11]}$ In an industrially relevant process that is carried out on multimillion tonne scales every year, ethylene oxide is generated from ethylene and dioxygen, where the product epoxide is an important building block in the synthesis of polyethyleneglycol. ${ }^{[3,4]}$ Biomimetic systems with iron heme complexes are also known to catalyse the epoxidation of alkenes. ${ }^{[9,10]}$ In addition, there are a number of copper based systems that utilize aldehyde reductants that can affect this transformation. ${ }^{[5,12]}$ Despite these successes, most of these reactions produce free peroxide species in solution (although in the biomimetic systems these are iron-oxo species). These long lived intermediates can be problematic with respect to selectivity, especially if there are multiple reactive sites in a substrate of interest.

Unlike synthetic and industrial chemists, nature is adept at selectively using dioxygen as an oxygen source for a number of aerobic transformations. In particular, mononuclear non-heme iron enzymes (MNHEs) can catalyse monooxygenation, dioxygenation and epoxidation reactions. ${ }^{[13-16]}$ The enzymatic active site contains a high spin iron(II) core that can activate molecular oxygen and generate reactive iron-oxo species. These oxidizing intermediates can then attack nearby substrates and facilitate selective reactions. ${ }^{[13-21]}$ A key feature of this process is the positioning of the substrates close to the reactive species, which splits $\mathrm{O}_{2}$ in a reliable and controlled manner, as seen for naphthalene dioxygenase (Scheme 1). [13-21] This molecular recognition constrains the reactive intermediates and directs their oxidizing potential towards a compound of choice.

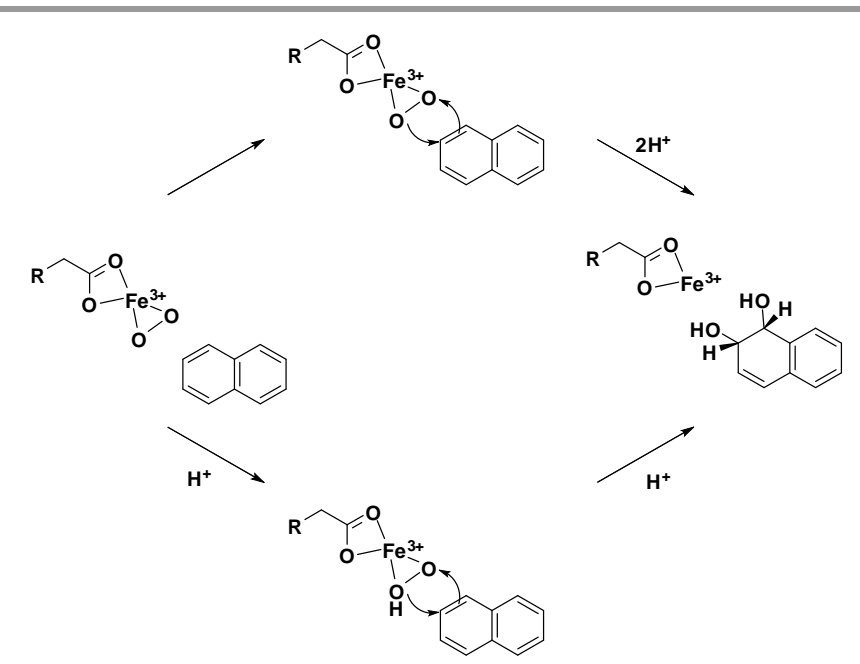

Scheme 1. Proposed mechanism for naphthalene dioxygenase. ${ }^{[21]}$

Moreover, $\mathrm{O}_{2}$ splitting is a 4-electron reduction process. In Scheme 1 the naphthalene provides two electrons, while enzymatic co-factors and the iron active site provide the other reducing equivalents. ${ }^{[13-21]}$ The availability of all 4 electrons required to reduce $\mathrm{O}_{2}$ is crucial for preventing the formation and release of highly-reactive, partially-reduced oxygen species, which can degrade the catalytic system. Studies examining oxygen reduction catalysts by Collman et al. and Love et al. have demonstrated this important concept in further detail. $^{[22-27]}$

We have recently described the reaction of ruthenium pentamethylcyclopentadienyl $\left(\mathrm{Cp}^{*}\right)$ complexes supporting 1,1,2-tris(diphenylphosphino)ethane (tppe) ligands with KOtBu in aprotic solvents. ${ }^{[28,29]}$ The strong base lead to the fragmentation of the tppe ligand in an elimination reaction, producing a terminal diphenylphosphido ligand, as well as 1,2bis(diphenylphosphino)ethene

(dppen); $\mathrm{RuCp} *\left(\mathrm{PPh}_{2} \mathrm{CH}=\mathrm{CHPPh} 2\right)\left(\mathrm{PPh}_{2}\right), \mathbf{1}($ Scheme 2$) \cdot{ }^{[28]}$ In the crystal structure of $\mathbf{1}$, the reactive phosphido functionality was in close 
proximity to the alkene backbone, which suggested that small molecules could be activated in this cleft. ${ }^{[28]}$ Herein, we report the reaction of $\mathbf{1}$ with molecular oxygen in a 4 electron reduction process and explore the mechanism of this transformation.

\section{Results and Discussion}

\section{Reactions with Dioxygen}

Complex 1 was subjected to a number of small molecules, including $\mathrm{H}_{2}$ and $\mathrm{N}_{2}$ gas, but was unreactive towards these substrates. When 1 was exposed to air, on the other hand, a colour change from the red to yellow was seen. The ${ }^{31} \mathrm{P}\left\{{ }^{1} \mathrm{H}\right\}$ NMR indicated that oxidation of the phosphido ligand had taken place as the phosphorus resonance shifted downfield from 23.2 ppm in 1 to 71.0 ppm. ${ }^{[28]}$ Formation of a $\mathrm{P}=\mathrm{O}$ bond, however, was not the only oxidation event that had occurred. In the ${ }^{1} \mathrm{H}$ NMR, the absence of alkene signals between 7.4 and $7.2 \mathrm{ppm}$ and the presence of aliphatic protons at $3.7 \mathrm{ppm}$ hinted that activation of dppen backbone had also taken place. ${ }^{[28]}$ This observation was supported by HRMS, $\mathrm{m} / \mathrm{z}^{+}$848.2, $\left[\mathrm{C}_{48} \mathrm{H}_{48} \mathrm{O}_{2} \mathrm{P}_{3} \mathrm{Ru}\right]^{+}$, which indicated that two oxygen atoms had been incorporated into the metal complex, 2 . These results revealed that epoxidation of the dppen backbone, as well as oxidation of the phosphido ligand had occurred (Scheme 2).

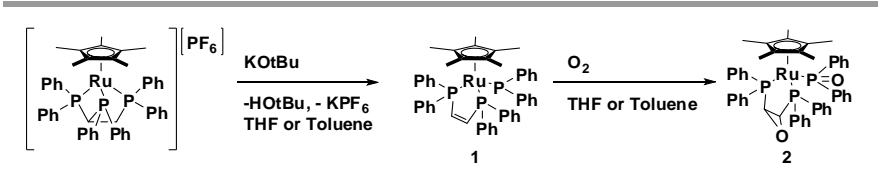

Scheme 2. Synthesis and oxidation of $\mathbf{1}$ using molecular oxygen.

The crystal structure of $\mathbf{2}$ confirmed these results, as both a phosphinito and an epoxide were evident (Figure 1). The $\mathrm{C}(1)$ $\mathrm{C}(2)$ bond length was indicative of a single bond, 1.473(9) $\AA$, while the $\mathrm{C}(1)-\mathrm{O}(1)$ and $\mathrm{C}(2)-\mathrm{O}(1)$ bonds were within the normal range for epoxides, $1.439(9)$ and $1.437(9) \AA$, respectively. ${ }^{[30]}$ Furthermore, the $\mathrm{P}(3)-\mathrm{O}(2)$ bond length was diagnostic for a $\mathrm{P}$ O double bond, 1.519(5) $\AA$ (for other notable bond lengths and angles see Table S1). ${ }^{[31]}$ It is interesting to note that only the "endo" isomer was generated, with the epoxide oxygen tucked under the ruthenium centre (also only one species in solution was seen by ${ }^{31} \mathrm{P}$ NMR). This suggested an intramolecular, ligandbased mechanism for $\mathrm{O}_{2}$ splitting.

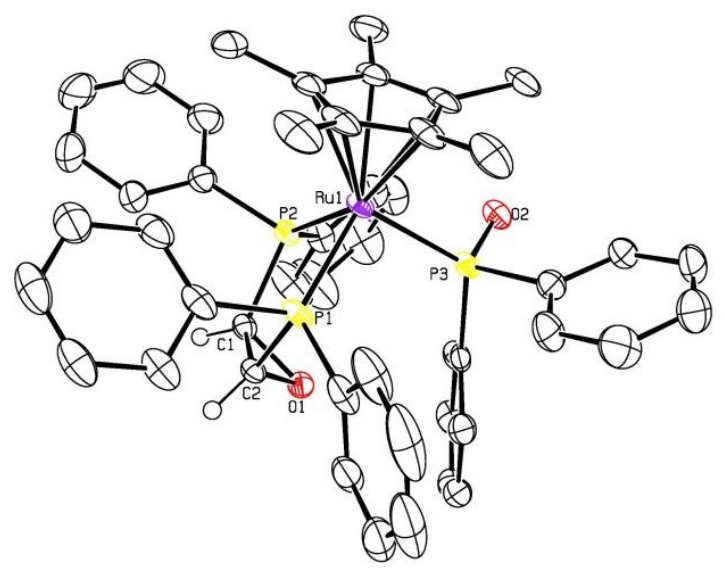

Figure 1. ORTEP3 representation (thermal ellipsoids at 50\% probability; most of the hydrogens are omitted for clarity) and atom numbering for $\mathbf{2}$.

In order to probe the nature of the epoxidation process, VT NMR studies were conducted. A ${ }^{31} \mathrm{P}\left\{{ }^{1} \mathrm{H}\right\}$ NMR of the reaction mixture at $-80^{\circ} \mathrm{C}$ revealed three species in solution: starting material, product, and small amounts of another species with broad signals around 77.6 and $60.3 \mathrm{ppm}$. Upon heating the sample to $-60^{\circ} \mathrm{C}$ the intermediate disappeared while the product grew in intensity (see Supporting Information, Figure S1). The chemical shift of the peak at $60.3 \mathrm{ppm}$ suggested that the phosphido ligand had been oxidized (shifted downfield from $23.2 \mathrm{ppm}$ in 1), while the dppen phosphorus nuclei were mainly undisturbed (77.6 ppm versus $82.0 \mathrm{ppm}$ for 1). ${ }^{[28]}$ Trapping studies with cyclooctene were also performed to determine if the reaction was occurring in an intermolecular fashion. Complex $\mathbf{1}$ was dissolved in almost neat cyclooctene (some THF-d8 was added to solubilize the ruthenium species) and air was injected into the sample. The ${ }^{31} \mathrm{P}\left\{{ }^{1} \mathrm{H}\right\}$ NMR showed that 2 had formed, while the ${ }^{1} \mathrm{H}$ NMR contained no cyclooctene oxide peaks.

Crossover experiments utilizing isotopically enriched ${ }^{18} \mathrm{O}_{2}$ gas, as well as pure ${ }^{16} \mathrm{O}_{2}$, were also conducted. Complex 1 was dissolved in THF and the reaction vial was sealed with a rubber septum. Half an equivalent of ${ }^{18} \mathrm{O}_{2}$, with respect to ruthenium starting material, as well as half an equivalent of ${ }^{16} \mathrm{O}_{2}$ were then simultaneously injected into the sealed vial. The reaction was allowed to proceed to completion and a mass spectrum was obtained of the resulting isotopomers. The product distribution was very close to an ideal 50:50 mixture of the all ${ }^{18} \mathrm{O}$ species and the all ${ }^{16} \mathrm{O}$ species (Figure 2a). This conclusively demonstrated that the oxygen splitting reaction proceeded through an intramolecular reaction, as significant amounts of the mixed ${ }^{18} \mathrm{O}^{16} \mathrm{O}$ species could not be detected (Figure $2 \mathrm{~b}$ ). 

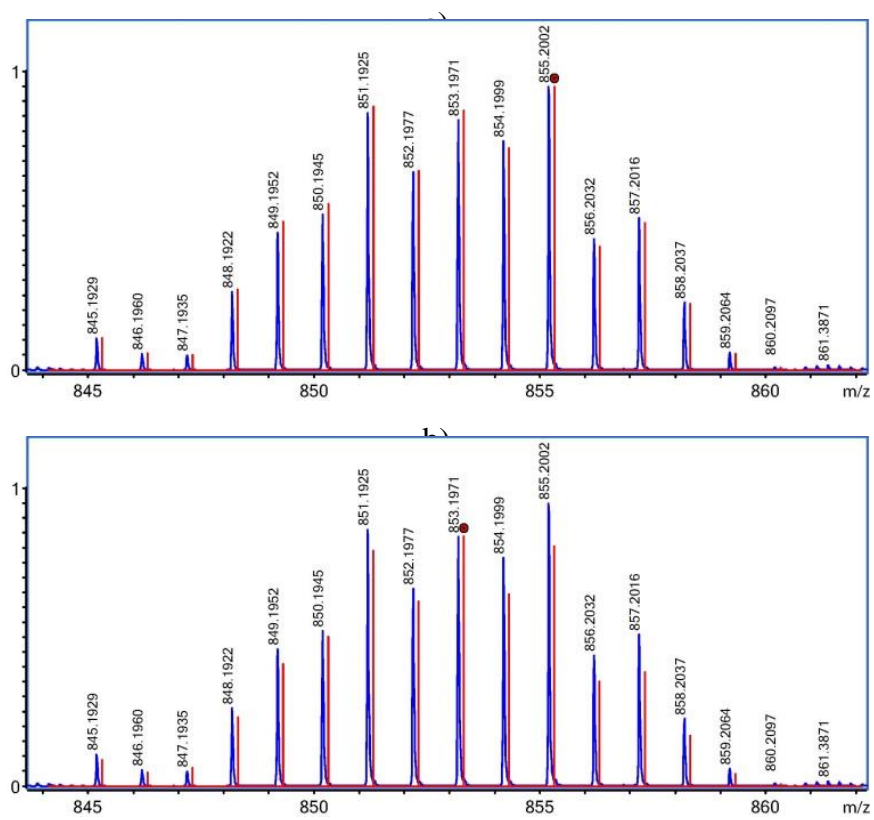

Figure 2. The experimentally determined $\mathrm{ESI}^{+}$spectrum of the crossover experiment (blue) versus a simulated spectrum (red) of: a) a 48:52 mixture of the $\mathrm{C}_{48} \mathrm{H}_{49}{ }^{18} \mathrm{O}_{2} \mathrm{P}_{3} \mathrm{Ru}^{+}$and $\mathrm{C}_{48} \mathrm{H}_{49}{ }^{16} \mathrm{O}_{2} \mathrm{P}_{3} \mathrm{Ru}^{+}$isotopomers; b) a 45:45:10 mixture of the $\mathrm{C}_{48} \mathrm{H}_{49}{ }^{18} \mathrm{O}_{2} \mathrm{P}_{3} \mathrm{Ru}^{+}, \quad \mathrm{C}_{48} \mathrm{H}_{49}{ }^{16} \mathrm{O}_{2} \mathrm{P}_{3} \mathrm{Ru}^{+}, \quad$ and $\mathrm{C}_{48} \mathrm{H}_{49}{ }^{18} \mathrm{O}^{16} \mathrm{OP}_{3} \mathrm{Ru}^{+}$isotopomers, respectively. Note that the red asterisk denotes the major peak in the simulated spectrum.

Based on the XRD data, the VT NMR studies, the cyclooctene trapping studies, and the crossover experiment we propose an intramolecular mechanism in which initial oxidation of the phosphido ligand produces an end-on peroxo species (Figure 3). This reactive phosphorus-peroxo moiety, which we predict is the intermediate that was observed by NMR, is then perfectly positioned next to the unsaturated dppen backbone, such that it can react in a selective fashion to produce an "endo" epoxide. We believe that the internal attack on the alkene backbone is so fast, and the lifetime of the intermediate is so short, that it cannot be intercepted by external alkenes. This type of mechanism is known in biological systems, where heme peroxidases, such as cytochrome $\mathrm{P} 450$, react with $\mathrm{O}_{2}$ to produce end-on iron peroxo species, which can be used to generate epoxides. ${ }^{[32-35]}$ Moreover, the positioning of the substrate close to the reactive, partially reduced oxygen intermediate is somewhat reminiscent of the naphthalene dioxygenase enzyme mentioned previously, in that the proximity of the substrate, in this case the alkene backbone, quenches the reactivity of the peroxo species, thus preventing uncontrolled side reactions. Furthermore, much like the natural system, all 4-electrons necessary to fully reduce $\mathrm{O}_{2}$ are present, which also explains why the reaction is so selective.

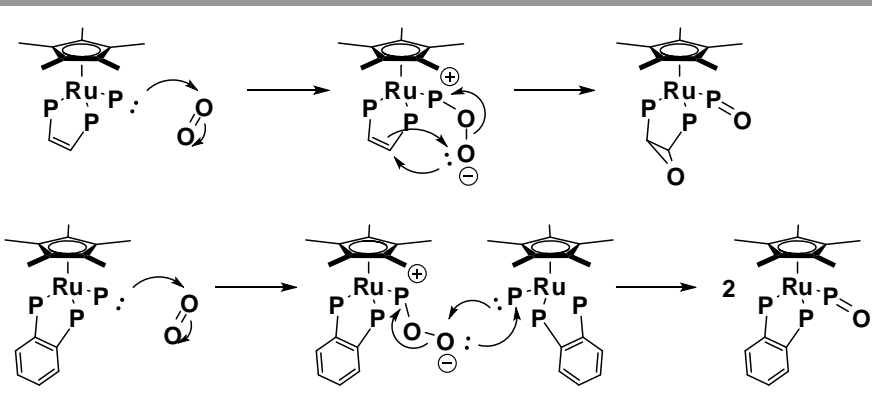

Figure 3. Proposed inter- and intramolecular mechanisms for $\mathbf{2}$ and $\mathbf{4}$. Note that the phenyl groups have been omitted for clarity.

Similar oxidation studies were performed with the previously reported ortho-phenylene analogue of $\mathbf{1}$; $\mathrm{RuCp} *\left(\mathrm{Ph}_{2} \mathrm{PC}_{6} \mathrm{H}_{4} \mathrm{PPh}_{2}\right)\left(\mathrm{PPh}_{2}\right)(3) .{ }^{[28]}$ Unlike the dppen variant, the 1,2-bis(diphenylphosphino)benzene (dppbz) ligand did not get oxidized, as shown by DART HRMS $\left(\mathrm{m} / \mathrm{z}^{+}\right.$885.2, $\left[\mathrm{C}_{52} \mathrm{H}_{50} \mathrm{OP}_{3} \mathrm{Ru}\right]^{+}$) and ${ }^{1} \mathrm{H}$ NMR (aromatic backbone protons detected, Scheme 3).

This indicated that the oxidation of $\mathbf{3}$ must have proceeded through a different mechanism than the intramolecular process discussed earlier for $\mathbf{1}$, and that an alternative intermolecular reduction of $\mathrm{O}_{2}$ needed to be considered in its place (Figure 3). We propose initial formation of an end-on phosphorus-peroxo species, much like the proposed intermediate for the oxidation of the dppen system, except that the peroxo species in this case cannot oxidise the dppbz backbone, but instead reacts with another equivalent of $\mathbf{3}$. In this way, two equivalents of $\mathbf{3}$ are required to split one equivalent of $\mathrm{O}_{2}$, which was reflected experimentally by the fact that only half an equivalent of dioxygen (half the volume of air that was necessary to fully oxidize an equivalent amount of $\mathbf{1}$ ) was needed to fully oxidize 3 and generate 4. Moreover, trapping studies with cyclooctene revealed small amounts of cyclooctene oxide in the ${ }^{1} \mathrm{H}$ NMR, thus supporting an intermolecular mechanism.

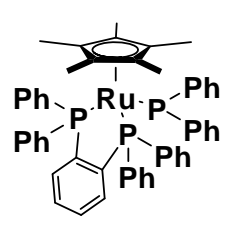

3

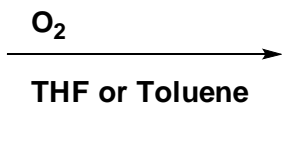

Scheme 3. Reactivity of complex 3 with $\mathrm{O}_{2}$.

The alternative process seen for the oxidation of $\mathbf{3}$ further reinforces the parallels between the epoxidation seen in the generation of $\mathbf{2}$ and the molecular recognition that is vital for naphthalene dioxygenase activity. If the alkene in $\mathbf{1}$ were not perfectly positioned to react with the phosphorus-oxo intermediate, then it is likely that an intermolecular reaction would have occurred instead, and only the phosphido ligands would have been oxidized, as seen with $\mathbf{3}$. 


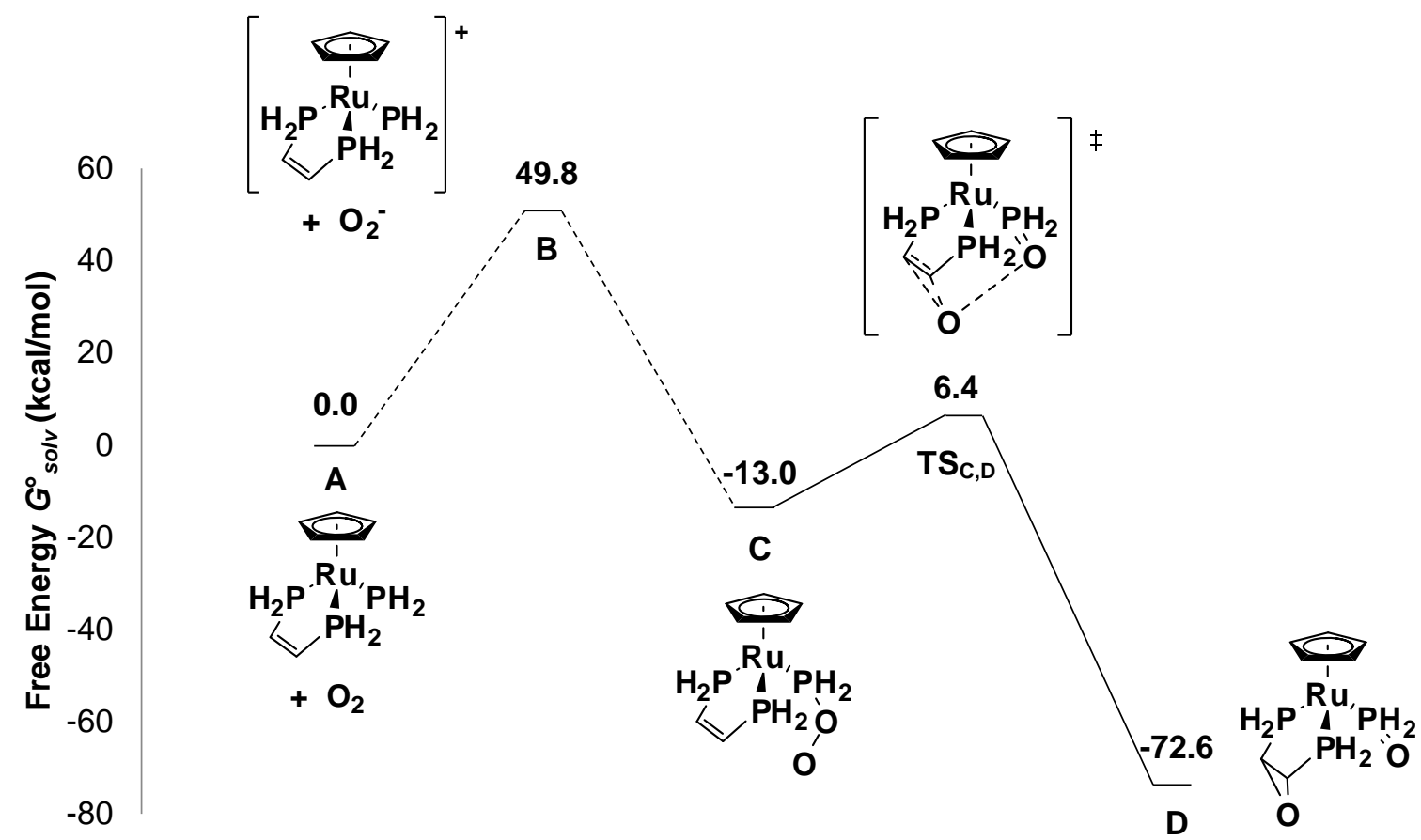

Figure 4. Energy profile for the oxygen splitting reaction (m06/6-31++G(d,p)/SDD-Ru/IEF-PCM + SMD(THF)). All energies are relative to A and $\mathrm{O}_{2}$.

\section{DFT Studies}

Detailed computational studies using the model complex $\mathbf{A}$, $\left[\mathrm{Ru}\left(\eta^{5}-\mathrm{C}_{5} \mathrm{H}_{5}\right)\left(\left(\mathrm{PH}_{2}\right)_{2} \mathrm{CHCH}_{2} \mathrm{PH}_{2}\right]^{+}\right.$(all the phenyl and methyl groups were removed to reduce computational costs), were conducted in order to gain further insight into the $\mathrm{O}_{2}$ splitting mechanism (Figures 4,5). The studies were based on the initial presence of $\mathbf{A}$ and molecular oxygen, and as such all energies were compared to these species. From this starting point, outersphere electron reduction of $\mathrm{O}_{2}$ was considered $(\mathbf{A} \rightarrow \mathbf{B})$, followed by rebound to form an end-on peroxo species $(\mathbf{B} \rightarrow \mathbf{C})$, and then splitting of $\mathrm{O}_{2}$ to produce the epoxide product $(\mathbf{C} \rightarrow \mathbf{D})$.

Calculations showed that the outer-sphere electron reduction of $\mathrm{O}_{2}$ to generate $\mathrm{O}_{2}^{-}$and $\mathbf{B}$ was very energetically demanding: $49.8 \mathrm{kcal} / \mathrm{mol}$. On-going from the ruthenium(III) intermediate to the end-on peroxo species $\mathbf{C}$, however, there was a large drop in energy down to $-13.0 \mathrm{kcal} / \mathrm{mol}$. A moderate activation barrier of $19.4 \mathrm{kcal} / \mathrm{mol}$ for $\mathbf{C} \rightarrow \mathbf{D}$ led to the transition state $\mathbf{T S} \mathbf{S}_{\mathbf{C}, \mathbf{D}}$ where the $\mathrm{O}-\mathrm{O}$ bond was broken and a $\mathrm{P}-\mathrm{O}$ double bond, as well as two C-O single bonds, were made. The final product $\mathbf{D}$ was found to be very stable at $-72.6 \mathrm{kcal} / \mathrm{mol}$ (selected ground state and transition state geometries are shown in Figure 5).

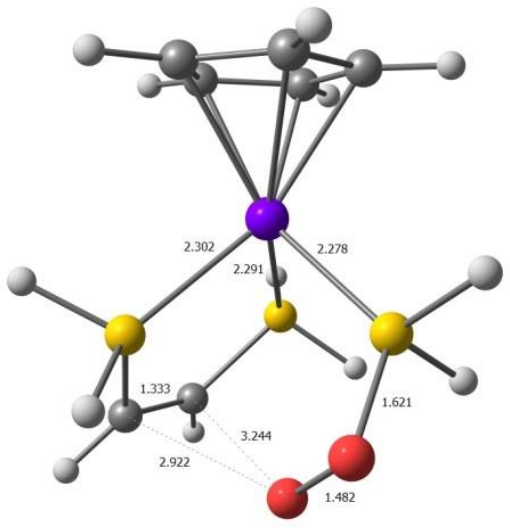

C

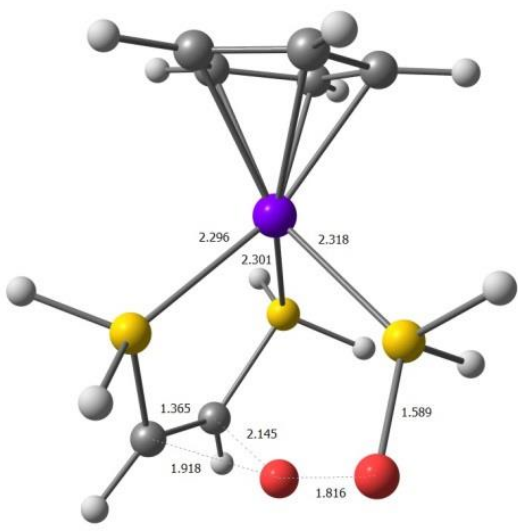

$\mathrm{TS}_{\mathrm{C}, \mathrm{D}}$

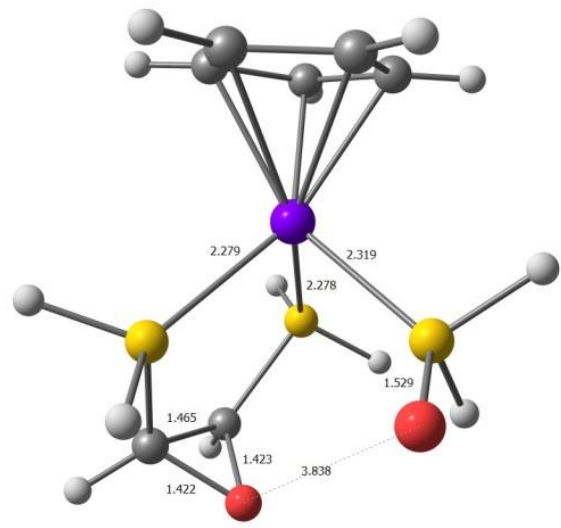

D

Figure 5. Optimized structures (m06/6-31++G(d,p)/SDD-Ru/IEF-PCM + SMD(THF)) as well as selected bond lengths $(\AA)$ of $\mathbf{C}$, TSC,D $\left(363 i\right.$ cm $\left.{ }^{-1}\right)$, and $\mathbf{D}$.

Despite the unreasonably high energy calculated for $\mathbf{B}$, our computational studies do support our oxygen-splitting mechanism in that a low energy end-on phosphorus-peroxo intermediate was found. In addition, $\mathbf{C}$ led directly to the product 
epoxide with a reasonable activation barrier, giving theoretical evidence for the structure of the proposed species. With respect to the outer sphere reduction of $\mathrm{O}_{2}$, it should be noted that the system was greatly simplified, and, if all the methyl and phenyl groups were included in the calculations, the energy of the ruthenium(III) complex could be significantly lower. Furthermore, DFT methods are capable of accurately modelling and comparing the energies of charged species or neutral species, but often have difficulty combining the two. ${ }^{[36]}$ This could also account for the disproportionately high energy calculated for the cationic complex $\mathbf{B}$, in comparison to the other neutral species.

\section{Electrochemical Studies}

Following the DFT studies, an electrochemical analysis of $\mathbf{1}$ in THF was conducted in order to verify that the neutral ruthenium species was capable of reducing $\mathrm{O}_{2}$ to superoxide. Scan rates of $100,150,200$, and $400 \mathrm{mVs}^{-1}$ were carried out in both positive and negative directions, with no detectable difference between the two routes (scan rates lower than 100 $\mathrm{mVs}^{-1}$ did not generate reproducible traces and lead to rapid decomposition of the phosphido complex). Two quasi-reversible redox couples were detected with an $E_{p a}$ and $E_{p c}$ of $0.51 \mathrm{~V}$ and $0.25 \mathrm{~V}$, as well as $-0.48 \mathrm{~V}$ and $-0.73 \mathrm{~V}$ vs. SCE, which we tentatively assign as metal- and ligand-based, respectively (Figure 6 and Supporting Information). The $E_{p a}$ for the most reducing redox couple (1) was very close to the literature value for the $\mathrm{E}_{1 / 2}$ of superoxide in $\mathrm{CH}_{3} \mathrm{CN}$ vs. $\mathrm{SCE}$ (2), and as such the overall redox reaction had a modest potential of $-0.22 \mathrm{~V}(3) .^{[37]}$ This corresponds to $\Delta \mathrm{G}=5.1 \mathrm{kcal} / \mathrm{mol}$, which is considerably lower in energy than the value from DFT (Figure 4 vs Figure 6b).

Although these are rough calculations (the redox potential for superoxide was not measured in THF and the electrochemical analysis of 1 could not be run in $\mathrm{CH}_{3} \mathrm{CN}$ because the ruthenium species decomposes in solution) they qualitatively show that the outer sphere-electron reduction of $\mathrm{O}_{2}$ is not as unreasonable as the DFT studies suggest. Moreover, the $\mathrm{E}_{1 / 2}$ for the outer sphere reduction of molecular oxygen by heme proteins can be as high as $-0.37 \mathrm{~V}$, which gives $\Delta \mathrm{G}=8.5 \mathrm{kcal} / \mathrm{mol}$. Despite being a nonspontaneous reaction, an outer sphere mechanism is commonly invoked to explain the reactivity and kinetics of these iron systems. ${ }^{[14,15,37-41]}$

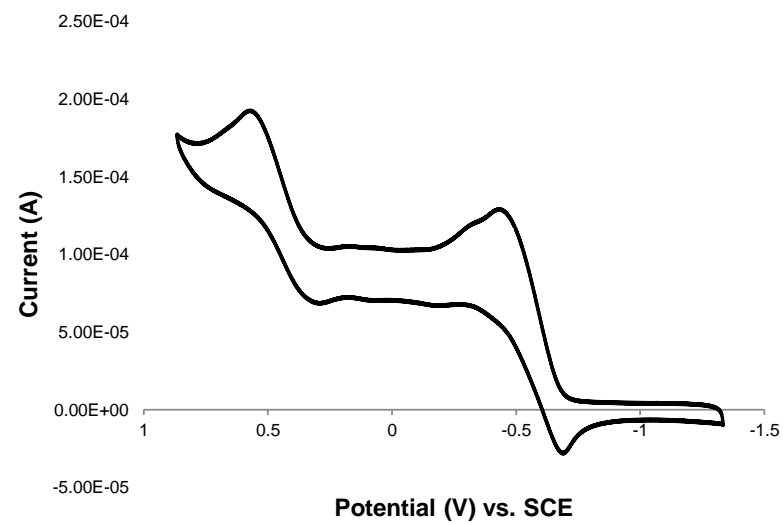

a)

b)

\begin{tabular}{rlrl}
$\operatorname{RuCp}^{*}\left(\mathrm{Ph}_{2} \mathrm{PCHCHPPh}_{2}\right)\left(\mathrm{PPh}_{2}\right)$ & $\longrightarrow \mathrm{RuCp}^{*}\left(\mathrm{Ph}_{2} \mathrm{PCHCHPPh}_{2}\right)\left(\mathrm{PPh}_{2}\right)^{+}+\mathrm{e}^{-}$ & $\mathrm{E}_{\mathrm{pa}}=0.48 \mathrm{~V}$ \\
$\mathrm{O}_{2}+\mathrm{e}^{-} \longrightarrow \mathrm{O}_{2}^{-}$ & $\mathrm{E}_{1 / 2}=-0.70 \mathrm{~V}$ \\
\hline $\operatorname{RuCp}^{*}\left(\mathrm{Ph}_{2} \mathrm{PCHCHPPh}_{2}\right)\left(\mathrm{PPh}_{2}\right)+\mathrm{O}_{2} \longrightarrow \mathrm{RuCp}^{*}\left(\mathrm{Ph}_{2} \mathrm{PCHCHPPh}_{2}\right)\left(\mathrm{PPh}_{2}\right)^{+}+\mathrm{O}_{2}^{-}$ & $\mathrm{E}_{\mathrm{rxn}}=-0.22 \mathrm{~V}$
\end{tabular}
$0.00 \mathrm{~V}$ produced redox features in this region identical to those shown here; b) calculation of the redox potential for the reduction of oxygen by $\mathbf{1}$ to superoxide.

\section{Reactions with Elemental Sulphur}

In addition to $\mathrm{O}_{2}$, the reactivity of complex 1 with respect to molecular sulphur was explored. Much like the reaction of $\mathbf{3}$ with dioxygen, only the phosphido ligand was oxidized, while the bidentate backbone remained untouched (Scheme 4). This is most likely due to the lower oxidation potential of sulphur in 
comparison to that of oxygen, such that any reactive intermediates may not have been oxidizing enough to attack the alkene backbone.

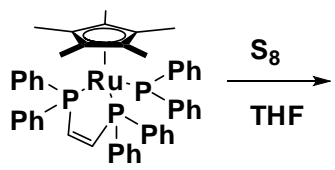

1

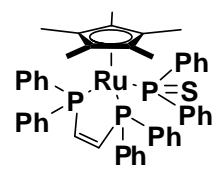

5
Scheme 4. Oxidation of 1 using elemental sulphur.

Moreover, assuming that the elemental sulphur was sufficiently oxidizing, the crystal structure of the sulphonated product, $\mathbf{5}$, indicates that the alkene backbone would most likely not have formed a thioepoxide, notwithstanding. The spacefilling model shows that the ruthenium complex is too crowded to accommodate two sterically demanding sulphur atoms (Figure 7).

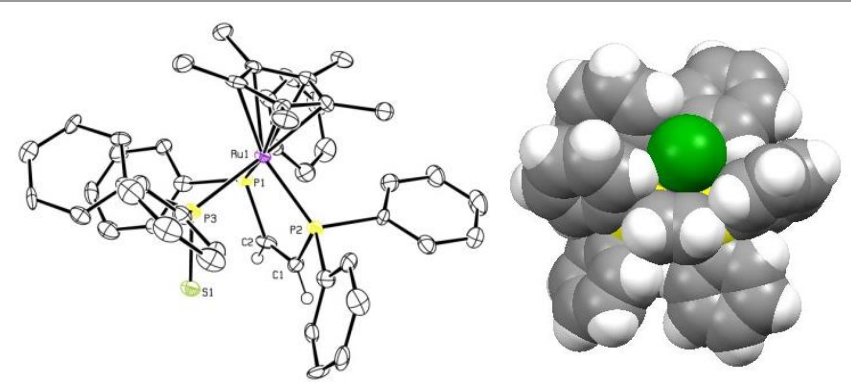

Figure 7. ORTEP3 representation (thermal ellipsoids at 50\% probability; most of the hydrogens are omitted for clarity) and atom numbering for $\mathbf{5}$ (left) as well as a space-filling model of the structure (right).

The increased steric demand of the sulphur atom is reflected in the NMR spectra of the oxidized product. Crystals of 5 were dissolved in deuterated THF and two separate species could be detected in solution. We attribute this to limited rotation about the ruthenium thiophosphinito bond on the same timescale as the NMR experiment.

It seems that the cleft between the alkene backbone and the phosphido ligand is the optimal size for splitting $\mathrm{O}_{2}$, but cannot accommodate larger substrates. This further reinforces the idea of molecular recognition with respect to complex $\mathbf{2}$ and molecular oxygen.

\section{Conclusions}

In summary, we have shown the reaction of complex 1 with molecular oxygen in a rare, ligand-based process, of which there are few related examples in the literature, ${ }^{[40,42-47]}$ where both oxygen atoms are utilized, in this case, to generate a phosphinito ligand and an epoxide. The reaction is selective for the reduction of $\mathrm{O}_{2}$, as larger, less oxidizing substrates, such as $\mathrm{S}_{8}$, and small molecules that do not undergo a 4-electron reduction process did not demonstrate the same reactivity. Although not catalytic, this system demonstrates a completely synthetic approach to using air directly in the production of epoxides; a process that generally requires peroxides as oxidizing agents or catalysts that can generate free peroxides in situ. ${ }^{[4,48-58]}$ The direct use of oxygen in air, however, is much more attractive, as it is an abundant, cheap, and completely green reagent. A crucial aspect of future catalyst design is the concept of molecular recognition and the arrangement of substrates and reactive species in specialized clefts or "active sites", such that a desired reaction proceeds in a controlled and selective manner.

\section{Experimental}

General Considerations. All procedures and manipulations were performed under an argon or nitrogen atmosphere using standard Schlenk-line and glove box techniques unless stated otherwise. All solvents were degassed and dried using standard procedures prior to all manipulations and reactions unless stated otherwise. The syntheses of complexes $\mathbf{1}$ and $\mathbf{3}$ were described previously. ${ }^{[28]}$ Deuterated solvents were purchased from Cambridge Isotope Laboratories or Sigma Aldrich, degassed, and dried over activated molecular sieves prior to use. All other reagents were purchased from commercial sources and utilized without further purification. The ESI-MS data was collected on an $\mathrm{AB} / \mathrm{Sciex}$ QStar mass spectrometer with an ESI source, the EI-MS data was collected on a Waters GC ToF mass spectrometer with an EI/CI source, and the DART-MS data was collected on a JOEL AccuTOF-DART mass spectrometer with a DART-ion source (no solvent is required). NMR spectra were recorded at ambient temperature and pressure using a Varian Gemini $400 \mathrm{MHz}$ spectrometer $\left(400 \mathrm{MHz}\right.$ for ${ }^{1} \mathrm{H}, 100 \mathrm{MHz}$ for ${ }^{13} \mathrm{C}, 376 \mathrm{MHz}$ for ${ }^{19} \mathrm{~F}$, and $161 \mathrm{MHz}$ for ${ }^{31} \mathrm{P}$ ) or an Agilent DD2$600 \mathrm{MHz}$ spectrometer $\left(600 \mathrm{MHz}\right.$ for ${ }^{1} \mathrm{H}, 151 \mathrm{MHz}$ for ${ }^{13} \mathrm{C}, 564$ $\mathrm{MHz}$ for ${ }^{19} \mathrm{~F}$, and $243 \mathrm{MHz}$ for ${ }^{31} \mathrm{P}$ ) unless stated otherwise. The ${ }^{1} \mathrm{H}$ and ${ }^{13} \mathrm{C}$ NMR were measured relative to partially deuterated solvent peaks but are reported relative to tetramethylsilane (TMS). All ${ }^{31} \mathrm{P}$ chemical shifts were measured relative to $85 \%$ phosphoric acid as an external reference. The elemental analyses were performed at the Department of Chemistry, University of Toronto, on a Perkin-Elmer $2400 \mathrm{CHN}$ elemental analyser. Single-crystal X-ray diffraction data were collected using a Nonius Kappa-CCD or Bruker Kappa APEX DUO diffractometer with Mo $\mathrm{K} \alpha$ radiation $(\lambda=0.710 \AA)$ or $\mathrm{Cu} \mathrm{K} \alpha$ radiation $(\lambda=2.29 \AA)$. The CCD data were integrated and scaled using the Denzo-SMN package. The structures were solved and refined using SHELXTL V6.1. Refinement was by full-matrix least squares on $\mathrm{F}^{2}$ using all data.

Computational Details. Density functional theory calculations were performed using the Gaussian09 package $^{59}$ and the M06 hybrid functional. ${ }^{60-62}$ Ruthenium was treated with the SDD relativistic effective core potential and associated basic set, ${ }^{63,64}$ while all other atoms were treated with the $6-31++\mathrm{G}(\mathrm{d}, \mathrm{p}) .{ }^{65-67} \mathrm{~A}$ pruned $(99,590)$ integration grid was used throughout (Grid=UltraFine). The substituents on phosphorus and $\mathrm{Cp}^{*}$ were replaced with hydrogen atoms to reduce computational cost. Optimizations were performed in THF using the integral equation formalism polarizable continuum model (IEF-PCM) ${ }^{68}$, ${ }^{69}$ with radii and non-electrostatic terms from the SMD solvation model. ${ }^{70}$ Ground states were connected to their transition states by performing intrinsic reaction coordinate (IRC) calculations, ${ }^{71}$ 
and stationary points were characterized by normal-mode analysis. Open-shell triplet-state optimizations were performed for structures $\mathbf{C}$ and $\mathbf{D}$, but were considerably higher in energy than their singlet-state free energies (by 48.0 and $42.0 \mathrm{kcal} / \mathrm{mol}$, respectively). In addition, a triplet transition state connecting $\mathbf{C}$ and $\mathbf{D}$ could not be found, and a high-spin ground state for $\mathbf{B}$ could also not be found. All structures except $\mathrm{O}_{2}$ (triplet state), $\mathrm{O}_{2}^{-}$(doublet state), and $\mathbf{B}$ (doublet state) were modelled as closed-shell singlet states. Full vibrational and thermochemical analyses (1 atm, $298 \mathrm{~K}$ ) were performed on optimized structures to obtain solvent-corrected free energies $\left(\mathrm{G}^{\circ}\right)$ and enthalpies $\left(\mathrm{H}^{\circ}\right)$. Optimized ground states were found to have zero imaginary frequencies, while transition states were found to have one imaginary frequency. Three dimensional visualizations of calculated structures were generated by ChemCraft.

Electrochemical Details. Cyclic voltammetry was performed with a SP-200 Bio-Logic-Science Instruments potentiostat. A standard three-electrode cell equipped with a $2 \mathrm{~mm} \mathrm{Pt}$ mesh working electrode, a silver wire pseudo-reference electrode, and a Pt wire counter-electrode was used. The electrolyte was a 0.1 $M$ solution of $\left[\mathrm{nBu}_{4} \mathrm{~N}\right]\left[\mathrm{PF}_{6}\right]$ in $\mathrm{THF}$. Reported potentials are referenced to the ferrocenium/ferrocene couple versus the standard calomel electrode, SCE $(0.50 \mathrm{~V})$.

Crossover Experiment Mass Spectrometry. Electrospray ionization (ESI) mass spectra were acquired in positive ion mode using a 6538 UHD model quadrupole time-of-flight mass spectrometer (Agilent Technologies, Santa Clara, CA). Samples were introduced to the ESI source via loop injection into a mobile phase having composition $1: 1(v / v)$ methanol : $0.1 \%$ aqueous formic acid and flowing at a rate of $100 \mu \mathrm{L} / \mathrm{min}$. Neat samples were diluted first in $\mathrm{MeOH}$ and subsequently in mobile phase to appropriate concentrations from which aliquots of 1-2 $\mu \mathrm{L}$ were taken for injection.

MS Data Analysis and Isotopic Abundance Simulations. Mass spectrometry data was processed using the MassHunter Qualitative Analysis software package version B.00.6 SP1 (Agilent Technologies, Santa Clara, CA). Isotopic abundance distributions were computed using the Mass Mountaineer software package version 1.00 .58 (C2012 R.B. Cody).

\section{Synthesis of complex 2} (RuCp*(Ph RCHOCHPPh $\left._{2}\right)\left(\right.$ OPPh $\left.\left._{2}\right)\right)$. A small amount of 1 $(0.020 \mathrm{~g}, 0.023 \mathrm{mmol})$ was dissolved in THF $(5 \mathrm{~mL})$ in a sealed vial. Approximately $3 \mathrm{~mL}$ of air was added to the vial and the solution was stirred for $20 \mathrm{~min}$. The colour changed from deep red to yellow, and the solvent was removed under reduced pressure. The resulting yellow solid was washed with a small amount of cold toluene $(\sim 1 \mathrm{~mL})$ and dried overnight. Yield: $86.7 \%(0.018 \mathrm{~g})$. Crystals suitable for X-ray diffraction studies were grown from the slow diffusion of oxygen into a toluene solution of complex 1. ${ }^{1} \mathrm{H}$ NMR (400 MHz, $\left.\mathrm{CD}_{2} \mathrm{Cl}_{2}\right) \delta: 7.95$ (br $\mathrm{s}, 4 \mathrm{H}, \mathrm{Ar}-\mathrm{CH}), 7.64-7.65(\mathrm{~m}, 6 \mathrm{H}, \mathrm{Ar}-\mathrm{CH}), 7.36$ (t, 2H, Ar-CH, $J$ $=7.1 \mathrm{~Hz}), 7.28(\mathrm{t}, 4 \mathrm{H}, \mathrm{Ar}-\mathrm{CH}, J=7.3 \mathrm{~Hz}), 7.18-7.11(\mathrm{~m}, 4 \mathrm{H}, \mathrm{Ar}-$ $\mathrm{CH}), 6.89(\mathrm{t}, 2 \mathrm{H}, \mathrm{Ar}-\mathrm{CH}, J=7.1 \mathrm{~Hz}), 6.77(\mathrm{t}, 4 \mathrm{H}, \mathrm{Ar}-\mathrm{CH}, J=$
$7.3 \mathrm{~Hz}), 6.57(\mathrm{t}, 4 \mathrm{H}, \mathrm{Ar}-\mathrm{CH}, J=8.0 \mathrm{~Hz}), 3.74(\mathrm{t}, 2 \mathrm{H}, \mathrm{O}-\mathrm{CH}, J=$ $10.4 \mathrm{~Hz})$, and $1.35\left(\mathrm{~s}, 15 \mathrm{H}, \mathrm{Cp}^{*}-\mathrm{CH}_{3}\right) \mathrm{ppm} .{ }^{31} \mathrm{P}\left\{{ }^{1} \mathrm{H}\right\} \mathrm{NMR}(161$ $\mathrm{MHz}, \mathrm{CD}_{2} \mathrm{Cl}_{2}$ ) $\delta: 70.98(\mathrm{t}, J=42.3 \mathrm{~Hz}$ ), and 67.57 (br d, $J=42.3$ $\mathrm{Hz})$ ppm. ${ }^{13} \mathrm{C}\left\{{ }^{1} \mathrm{H}\right\}$ NMR (100 MHz, $\left.\mathrm{CD}_{2} \mathrm{Cl}_{2}\right) \delta: 139.54-139.43$ (m, C-P), 137.04-136.93 (m, C-P), 134.12-133.65 (m, Ar-CH), 133.27-133.12 (m, Ar-CH), 130.77 (d, Ar-CH, $J=9.9$ Hz), 130.04 (s, Ar-CH), 129.51(s, Ar-CH), 127.86-127.75 (m, Ar$\mathrm{CH}), 127.60-127.47$ (m, Ar-CH), 125.94-125.85 (m, Ar-CH), 125.54 (d, Ar-CH, $J=8.7 \mathrm{~Hz}$ ), 96.82-96.75 (m, Cp*-C), 58.72$58.56(\mathrm{~m}, \mathrm{O}-\mathrm{C})$, and $10.50\left(\mathrm{~s}, \mathrm{Cp}^{*} \mathrm{CH}_{3}\right) \mathrm{ppm}$. Anal. Calcd for $\left[\mathrm{C}_{48} \mathrm{H}_{47} \mathrm{O}_{2} \mathrm{P}_{3} \mathrm{Ru}\right]\left[\mathrm{C}_{4} \mathrm{H}_{10} \mathrm{O}\right]: \mathrm{C}, 67.59 ; \mathrm{H}, 6.22$. Found: C, 67.49; $\mathrm{H}$, 6.59. MS (DART, DCM; m/z $\mathrm{z}^{+}$): $848.2\left[\mathrm{C}_{48} \mathrm{H}_{48} \mathrm{O}_{2} \mathrm{P}_{3} \mathrm{Ru}\right]^{+}$.

Synthesis of complex $4\left(\mathrm{RuCp}^{*}\left(\mathrm{Ph}_{2} \mathrm{PC}_{6} \mathrm{H}_{4} \mathrm{PPh}_{2}\right)\left(\mathrm{OPPh}_{2}\right)\right)$. A small amount of $\mathbf{3}$ ( $0.040 \mathrm{~g}, 0.046 \mathrm{mmol}$ ) was dissolved in THF $(3 \mathrm{~mL})$ in a sealed vial. Approximately $3 \mathrm{~mL}$ of air was added to the vial and the solution was stirred for $30 \mathrm{~min}$. The colour gradually changed from deep red to yellow, and the solvent was removed under reduced pressure. The resulting yellow solid was dissolved in toluene $(\sim 2 \mathrm{~mL})$ and cooled to $-33{ }^{\circ} \mathrm{C}$ in a freezer overnight. The solution was filtered through Celite and the solvent was removed under reduced pressure to give a yellow powder. Yield: $89.3 \%$ (0.036 g). ${ }^{1} \mathrm{H}$ NMR (400 MHz, $\left.\mathrm{C}_{4} \mathrm{D}_{8} \mathrm{O}\right) \delta$ : 8.06-7.98 (m, 4H, Ar-CH), 7.34-7.38 (m, 4H, Ar-CH), 7.27-7.17 (m, 4H, Ar-CH), 7.17-7.07 (m, 12H, Ar-CH), 6.78-6.72 (m, 2H, Ar-CH), 6.65 -6.58 (m, 4H, Ar-CH), 6.54-6.46 (m, 4H, Ar-CH), and $1.28\left(\mathrm{~d}, 15 \mathrm{H}, \mathrm{Cp}^{*}-\mathrm{CH}_{3}, J=1.2 \mathrm{~Hz}\right) \mathrm{ppm} .{ }^{31} \mathrm{P}\left\{{ }^{1} \mathrm{H}\right\} \mathrm{NMR}(161$ $\mathrm{MHz}, \mathrm{C}_{4} \mathrm{D}_{8} \mathrm{O}$ ) $\delta: 90.79$ (br s), and 75.15 (d, $J=45.3 \mathrm{~Hz}$ ) ppm. ${ }^{13} \mathrm{C}\left\{{ }^{1} \mathrm{H}\right\}$ NMR $\left(100 \mathrm{MHz}, \mathrm{C}_{4} \mathrm{D}_{8} \mathrm{O}\right) \delta: 148.60$ (d, P-C, $J=38.4$ $\mathrm{Hz}$ ), 145.95 (t, P-C, $J=43.5 \mathrm{~Hz}), 140.20-138.48$ (m, P-C), 135.72 (dd, C-P, $J=23.5,3.4 \mathrm{~Hz}), 135.43-135.15$ (m, Ar-CH), 133.29 (t, Ar-CH, $J=5.0 \mathrm{~Hz}), 132.11$ (d, Ar-CH, $J=10.2 \mathrm{~Hz}$ ), 132.04 (t, Ar-CH, $J=8.3 \mathrm{~Hz}$ ), 128.39 (br s, Ar-CH), 128.32 (br s, Ar-CH), 126.92-126.68 (m, Ar-CH), 126.50 (d, Ar-CH, $J=2.1$ $\mathrm{Hz}), 125.30$ (d, Ar-CH, $J=8.7 \mathrm{~Hz}), 94.90$ (d, Cp*-C, $J=1.6 \mathrm{~Hz}$ ), and $9.89\left(\mathrm{~s}, \mathrm{Cp}^{*}-\mathrm{CH}_{3}, J=4.7 \mathrm{~Hz}\right) \mathrm{ppm}$. Anal. Calcd for [ $\left.\mathrm{C}_{52} \mathrm{H}_{49} \mathrm{OP}_{3} \mathrm{Ru}\right] 0.66\left[\mathrm{C}_{5} \mathrm{H}_{12}\right]: \mathrm{C}, 71.31 ; \mathrm{H}, 6.16$. Found: C, 71.25; $\mathrm{H}$, 6.65. MS (DART, no solvent; $\mathrm{m} / \mathrm{z}^{+}$): $885.2\left[\mathrm{C}_{52} \mathrm{H}_{50} \mathrm{OP}_{3} \mathrm{Ru}\right]^{+}$.

Synthesis of complex $5\left(\operatorname{RuCp}^{*}\left(\operatorname{Ph}_{2} \mathbf{P C H C H P P h}\right)\left(\mathrm{SPPh}_{2}\right)\right)$. A small amount of $\mathbf{1}(0.020 \mathrm{~g}, 0.023 \mathrm{mmol})$ was dissolved in THF (5 mL). Elemental sulphur $(0.006 \mathrm{~g}, 0.023 \mathrm{mmol})$ was added and the solution was stirred for $15 \mathrm{~min}$. The colour rapidly changed from deep red to yellow, and the solvent was removed under reduced pressure. The resulting yellow solid was dissolved in toluene $(\sim 2 \mathrm{~mL})$ and cooled to $-33{ }^{\circ} \mathrm{C}$ in a freezer overnight. The solution was filtered through Celite and the solvent removed under reduced pressure to give a yellow powder. Yield: $92.1 \%$ (0.019 g). Crystals suitable for X-ray diffraction studies were grown from the slow evaporation of a THF solution of complex 5. Isomer 1: ${ }^{1} \mathrm{H} N M R\left(600 \mathrm{MHz}, \mathrm{C}_{4} \mathrm{D}_{8} \mathrm{O},-35^{\circ} \mathrm{C}\right) \delta: 7.96(\mathrm{t}, 4 \mathrm{H}$, Ar-CH, $J=8.5 \mathrm{~Hz}), 7.77-7.64(\mathrm{~m}, 2 \mathrm{H}, \mathrm{CH}=\mathrm{CH}), 7.33-7.27(\mathrm{~m}$, $6 \mathrm{H}, \mathrm{Ar}-\mathrm{CH}), 7.22$ (t, 4H, Ar-CH, $J=8.1 \mathrm{~Hz}), 7.12(\mathrm{t}, 4 \mathrm{H}, \mathrm{Ar}-$ $\mathrm{CH}, J=8.5 \mathrm{~Hz}), 6.84-6.79(\mathrm{~m}, 6 \mathrm{H}, \mathrm{Ar}-\mathrm{CH}), 6.69$ (t, 6H, Ar-CH, $J=7.2 \mathrm{~Hz}$ ),_and $1.27\left(\mathrm{~s}, 15 \mathrm{H}, \mathrm{Cp}^{*}-\mathrm{CH}_{3}\right) \mathrm{ppm} .{ }^{31} \mathrm{P}\left\{{ }^{1} \mathrm{H}\right\} \mathrm{NMR}$ $\left(242 \mathrm{MHz}, \mathrm{C}_{4} \mathrm{D}_{8} \mathrm{O},-35^{\circ} \mathrm{C}\right) \delta: 71.86(\mathrm{~d}, J=38.2 \mathrm{~Hz})$, and 60.64 
$(\mathrm{t}, J=38.2 \mathrm{~Hz}) \mathrm{ppm} .{ }^{13} \mathrm{C}\left\{{ }^{1} \mathrm{H}\right\} \mathrm{NMR}\left(150 \mathrm{MHz}, \mathrm{C}_{4} \mathrm{D}_{8} \mathrm{O},-35^{\circ} \mathrm{C}\right)$ $\delta: 145.82(\mathrm{~d}, \mathrm{CH}-\mathrm{P}, J=32.8 \mathrm{~Hz}), 138.20(\mathrm{~d}, \mathrm{C}-\mathrm{P}, J=39.9 \mathrm{~Hz})$, 135.22 (d, C-P, $J=45.8 \mathrm{~Hz}$ ), 133.76 (d, Ar-CH, $J=7.8 \mathrm{~Hz}$ ), 133.27 (d, Ar-CH, $J=8.7 \mathrm{~Hz}$ ), 133.08 (d, Ar-CH, $J=11.3 \mathrm{~Hz}$ ), 128.93 (s, Ar-CH), 128.40(s, Ar-CH), 127.26 (d, Ar-CH, $J=7.8$ $\mathrm{Hz}), 126.83$ (d, Ar-CH, $J=8.9 \mathrm{~Hz}), 126.11(\mathrm{~s}, \mathrm{Ar}-\mathrm{CH}), 125.10$ (d, Ar-CH, $J=9.9 \mathrm{~Hz}), 94.19$ (s, Cp*-C), and 9.91 (s, $\left.\mathrm{Cp}^{*} \mathrm{CH}_{3}\right)$ ppm. Isomer 2: ${ }^{1} \mathrm{H}$ NMR $\left(600 \mathrm{MHz}, \mathrm{C}_{4} \mathrm{D}_{8} \mathrm{O},-35^{\circ} \mathrm{C}\right) \delta: 7.64-7.60$ (m, 2H, Ar-CH), 7.59-7.50 (m, 4H, Ar-CH), 7.48-7.36 (m, 6H, Ar-CH), 7.36-7.32 (m, 2H, Ar-CH, $J=7.3 \mathrm{~Hz}), 7.08-6.99$ (m, 4H, Ar-CH), 6.97-6.91 (m, 2H, Ar-CH), 6.90-6.84 (m, 4H, Ar$\mathrm{CH}), 6.45-6.37(\mathrm{~m}, 2 \mathrm{H}, \mathrm{Ar}-\mathrm{CH}, J=8.0 \mathrm{~Hz})$, and $1.55(\mathrm{~s}, 15 \mathrm{H}$, $\left.\mathrm{Cp}^{*}-\mathrm{CH}_{3}\right)$ ppm. ${ }^{31} \mathrm{P}\left\{{ }^{1} \mathrm{H}\right\} \mathrm{NMR}\left(242 \mathrm{MHz}, \mathrm{C}_{4} \mathrm{D}_{8} \mathrm{O},-35^{\circ} \mathrm{C}\right) \delta$ : 70.16 (br d, $J=36.4 \mathrm{~Hz}$ ), 65.34 (br d, $J=36.4 \mathrm{~Hz}$ ), and $62.23(\mathrm{t}$, $J=36.4 \mathrm{~Hz}) \mathrm{ppm} .{ }^{13} \mathrm{C}\left\{{ }^{1} \mathrm{H}\right\} \mathrm{NMR}\left(150 \mathrm{MHz}, \mathrm{C}_{4} \mathrm{D}_{8} \mathrm{O},-35^{\circ} \mathrm{C}\right) \delta$ : 145.42-145.14 (m, CH-P), 145.10-144.83 (m, CH-P), 143.00142.35 (m, C-P),138.12-137.61 (m, C-P), 136.84-136.45 (m, C$\mathrm{P}), 134.05-133.81$ (m, Ar-CH), 132.98-132.77 (m, Ar-CH), 132.68-132.37 (m, Ar-CH), 129.57-129.30 (m, Ar-CH), 129.24129.02 (m, Ar-CH), 128.20-128.05 (m, Ar-CH), 127.19-126.87 (m, Ar-CH), 126.77-126.52 (m, Ar-CH), 125.80-125.59 (m, Ar$\mathrm{CH})$, 125.35-125.09 (m, Ar-CH), 95.58 (s, Cp*-C), and 10.53 (s, $\left.\mathrm{Cp}^{*} \mathrm{CH}_{3}\right) \quad$ ppm. Anal. Calcd for $\left[\mathrm{C}_{48} \mathrm{H}_{47} \mathrm{P}_{3} \mathrm{RuS}\right] 0.33\left[\mathrm{C}_{7} \mathrm{H}_{8}\right] 0.33\left[\mathrm{C}_{4} \mathrm{H}_{8} \mathrm{O}\right]: \mathrm{C}, 68.59 ; \mathrm{H}, \quad 5.83$. Found: C, 68.54; H, 5.83. MS $\left(\mathrm{ESI}^{+}, \mathrm{DCM} ; \mathrm{m} / \mathrm{z}^{+}\right): 851.2$ $\left[\mathrm{C}_{48} \mathrm{H}_{48} \mathrm{P}_{3} \mathrm{RuS}\right]^{+}$.

${ }^{18} \mathrm{O}_{2} /{ }^{16} \mathrm{O}_{2}$ Crossover Experiment. A small amount of $1(0.010$ $\mathrm{g}, 0.012 \mathrm{mmol}$ ) was dissolved in $2 \mathrm{~mL}$ THF in a vial sealed with a rubber septum. The two oxygen isotopomers, ${ }^{18} \mathrm{O}_{2}(0.15 \mathrm{~mL}$, $0.06 \mathrm{mmol})$ and ${ }^{16} \mathrm{O}_{2}(0.15 \mathrm{~mL}, 0.06 \mathrm{mmol})$ were then simultaneously injected into the vial. The solution was stirred for $30 \mathrm{~min}$. and the deep red solution turned bright yellow. The solvent was removed in vacuo, and the yellow solid was used for MS experiments.

\section{Acknowledgements}

We thank NSERC Canada for a Discovery grant to R. H. M, and Tyler Schon from the Seferos group for his assistance with cyclic voltammetry.

\section{Notes and References}

${ }^{a}$ Department of Chemistry, University of Toronto, Toronto, Ontario, M5S 3H6, Canada.E-mail: rmorris@chem.utoronto.ca

$\dagger$ Electronic Supplementary Information (ESI) available: Extended experimental section. Selected bond lengths and angles for $\mathbf{2}$ and $\mathbf{5}$. Crystallographic data tables for $\mathbf{2}$ and $\mathbf{5}$ (including CIF files). Discussion of the VT NMR studies. Discussion of the origin of the quasi-reversible redox couples for $\mathbf{2}$. Tables giving Cartesian coordinates and free energies for optimized structures. Text giving the complete ref 59. See DOI: $10.1039 / \mathrm{b} 000000 \mathrm{x} /$

1. Verkhovsky, M. I.; Morgan, J. E.; Wikstroem, M. Biochemistry 1994, 33, 3079-3086.
2. Shi, Z.; Zhang, C.; Tang, C.; Jiao, N. Chem. Soc. Rev. 2012, 41, 33813430 .

3. Rebsdat, S.; Mayer, D. Ethylene Oxide. In Ullmann's Encyclopedia of Industrial Chemistry, Wiley-VCH: Weinheim, 2000.

4. Kahlich, D.; Wiechern, U.; Lindner, J. Propylene Oxide. In Ullmann's Encyclopedia of Industrial Chemistry, Wiley-VCH: Weinheim, 2000.

5. Allen, S. E.; Walvoord, R. R.; Padilla-Salinas, R.; Kozlowski, M. C. Chem. Rev. 2013, 113, 6234-6458.

6. Jira, R. Angew. Chem. Int. Ed. 2009, 48, 9034-9037.

7. Hosseini-Monfared, H.; Meyer, H.; Janiak, C. J. Mol. Catal. A: Chem. 2013, 372, 72-78.

8. Punniyamurthy, T.; Velusamy, S.; Iqbal, J. Chem. Rev. 2005, 105, 2329-2364.

9. Piera, J.; Bäckvall, J.-E. Angew. Chem. Int. Ed. 2008, 47, 3506-3523.

10. Que, L.; Tolman, W. B. Nature 2008, 455, 333-340.

11. Sorokin, A. B. Chem. Rev. 2013, 113, 8152-8191.

12. Punniyamurthy, T.; Rout, L. Coord. Chem. Rev. 2008, 252, 134-154.

13. Kovaleva, E. G.; Lipscomb, J. D. Nat. Chem. Biol. 2008, 4, 186-193.

14. Bugg, T. D. H. Tetrahedron 2003, 59, 7075-7101.

15. Bugg, T. D. H.; Ramaswamy, S. Curr. Opin. Chem. Biol. 2008, 12, 134-140.

16. Lange, S. J.; Que, L. Curr. Opin. Chem. Biol. 1998, 2, 159-172.

17. Kovaleva, E. G.; Neibergall, M. B.; Chakrabarty, S.; Lipscomb, J. D. Acc. Chem. Res. 2007, 40, 475-483.

18. Costas, M.; Mehn, M. P.; Jensen, M. P.; Que, L. Chem. Rev. 2004, 104, 939-986.

19. Solomon, E. I.; Wong, S. D.; Liu, L. V.; Decker, A.; Chow, M. S. Curr. Opin. Chem. Biol. 2009, 13, 99-113.

20. Buongiorno, D.; Straganz, G. D. Coord. Chem. Rev. 2013, 257, 541563.

21. Karlsson, A.; Parales, J. V.; Parales, R. E.; Gibson, D. T.; Eklund, H.; Ramaswamy, S. Science 2003, 299, 1039-1042.

22. Collman, J. P.; Devaraj, N. K.; Decréau, R. A.; Yang, Y.; Yan, Y.-L.; Ebina, W.; Eberspacher, T. A.; Chidsey, C. E. D. Science 2007, 315, 1565-1568.

23. Collman, J. P.; Kaplun, M.; Decréau, R. A. Dalton Trans. 2006, 0, 554559.

24. Chang, C. J.; Loh, Z.-H.; Shi, C.; Anson, F. C.; Nocera, D. G., J. Am. Chem. Soc. 2004, 126, 10013-10020.

25. Devoille, A. M. J.; Love, J. B. Dalton Trans. 2012, 41, 65-72.

26. Boulatov, R.; Collman, J. P.; Shiryaeva, I. M.; Sunderland, C. J. J. Am. Chem. Soc. 2002, 124, 11923-11935.

27. Askarizadeh, E.; Yaghoob, S. B.; Boghaei, D. M.; Slawin, A. M. Z.; Love, J. B. Chem. Commun. 2010, 46, 710-712.

28. Sues, P. E.; Lough, A. J.; Morris, R. H. 2013, submitted.

29. Sues, P. E.; Lough, A. J.; Morris, R. H. Organometallics 2012, 31, 6589-6594.

30. Illa, O.; Gornitzka, H.; Branchadell, V.; Baceiredo, A.; Bertrand, G.; Ortuño, Rosa M. Eur. J. Org. Chem. 2003, 2003, 3147-3152.

31. Sues, P. E.; Lough, A. J.; Morris, R. H. Inorg. Chem. 2012, 51, 93229332.

32. Wang, D.; Thiel, W. J. Mol. Struct. (Theochem.) 2009, 898, 90-96.

33. Chen, H.; Ikeda-Saito, M.; Shaik, S. J. Am. Chem. Soc. 2008, 130, 14778-14790.

34. van Rantwijk, F.; Sheldon, R. A. Curr. Opin. Biotechnol. 2000, 11, 554-564. 
35. Wilson, S. A.; Kroll, T.; Decréau, R. A.; Hocking, R. K.; Lundberg, M.; Hedman, B.; Hodgson, K. O.; Solomon, E. I. J. Am. Chem. Soc. 2013, 135, 1124-1136.

36. Wu, Q.; Ayers, P. W.; Yang, W. J. Chem. Phys. 2003, 119, 2978-2990.

37. Kryatov, S. V.; Taktak, S.; Korendovych, I. V.; Rybak-Akimova, E. V.; Kaizer, J. Z.; Torelli, S. P.; Shan, X.; Mandal, S.; MacMurdo, V. L.; Mairata i Payeras, A.; Que, L. Inorg. Chem. 2004, 44, 85-99.

38. Gonzalez, G.; Gilles-Gonzalez, M. A.; Rybak-Akimova, E. V.; Buchalova, M.; Busch, D. H. Biochemistry 1998, 37, 10188-10194.

39. Shikama, K. Chem. Rev. 1998, 98, 1357-1374.

40. Tejel, C.; Del Río, M. P.; Ciriano, M. A.; Reijerse, E. J.; Hartl, F.; Záliš, S.; Hetterscheid, D. G. H.; Spithas, N. T. I.; De Bruin, B. Chem. - Eur. J. 2009, 15, 11878-11889.

41. Purdy, M. M.; Koo, L. S.; Ortiz de Montellano, P. R.; Klinman, J. P., Biochemistry 2006, 45, 15793-15806.

42. Chohan, B. S.; Maroney, M. J. Inorg. Chem. 2006, 45, 1906-1908.

43. Lee, C.-M.; Hsieh, C.-H.; Dutta, A.; Lee, G.-H.; Liaw, W.-F. J. Am. Chem. Soc. 2003, 125, 11492-11493.

44. McQuilken, A. C.; Jiang, Y.; Siegler, M. A.; Goldberg, D. P. J. Am. Chem. Soc. 2012, 134, 8758-8761.

45. Videla, M.; Roncaroli, F.; Slep, L. D.; Olabe, J. A. J. Am. Chem. Soc. 2006, 129, 278-279.

46. Ho, D. G.; Gao, R.; Celaje, J.; Chung, H.-Y.; Selke, M. Science 2003, 302, 259-262.

47. Mastrorilli, P.; Latronico, M.; Nobile, C. F.; Suranna, G. P.; Fanizzi, F. P.; Englert, U.; Ciccarella, G. Dalton Trans. 2004, 1117-1119.

48. Prileschajew, N. Ber. Dtsch. Chem. Ges. 1909, 42, 4811-4815.

49. Ishii, Y.; Sakaguchi, S.; Iwahama, T. Adv. Synth. Catal. 2001, 343, 393-427.

50. Habibi, D.; Faraji, A. R.; Arshadi, M.; Heydaria, S.; Gil, A. Appl. Catal. A 2013, 466, 282-292.

51. Tada, M.; Muratsugu, S.; Kinoshita, M.; Sasaki, T.; Iwasawa, Y. J. Am. Chem. Soc. 2009, 132, 713-724.

52. Tada, M.; Coquet, R.; Yoshida, J.; Kinoshita, M.; Iwasawa, Y. Angew. Chem. Int. Ed. 2007, 46, 7220-7223.

53. Tada, M.; Akatsuka, Y.; Yang, Y.; Sasaki, T.; Kinoshita, M.; Motokura, K.; Iwasawa, Y. Angew. Chem. Int. Ed. 2008, 47, 92529255.

54. Nishiyama, H.; Motoyama, Y. Chem. Commun. 1997, 1863-1864.

55. Liu, L.-L.; Li, H.-X.; Wan, L.-M.; Ren, Z.-G.; Wang, H.-F.; Lang, J.P. Chem. Commun. 2011, 47, 11146-11148.

56. Koya, S.; Nishioka, Y.; Mizoguchi, H.; Uchida, T.; Katsuki, T. Angew. Chem. Int. Ed. 2012, 51, 8243-8246.

57. Goberna-Ferrón, S.; Lillo, V.; Galán-Mascarós, J. R. N. Catal. Commun. 2012, 23, 30-33.

58. Oloo, W. N.; Fielding, A. J.; Que, L. J. Am. Chem. Soc. 2013, 135, 6438-6441.

59. Frisch, M. J. et. al., Gaussian 09, Revision B.01; Gaussian, Inc.: Wallingford CT, 2010. For the full reference, see the Supporting Information.

60. Kulkarni, A. D.; Truhlar, D. G. J. Chemical Theory Comput. 2011, 7, 2325-2332.

61. Zhao, Y.; Truhlar, D. Theor. Chem. Acc. 2008, 120, 215-241.

62. Zhao, Y.; Truhlar, D. G. J. Chem. Phys. 2006, 125, 194101-194118.

63. Leininger, T.; Nicklass, A.; Stoll, H.; Dolg, M.; Schwerdtfeger, P. Journal Chem. Phys. 1996, 105, 1052-1059.
64. Andrae, D.; Häußermann, U.; Dolg, M.; Stoll, H.; Preuß, H. Theor. Ahim. Acta 1990, 77, 123-141.

65. Clark, T.; Chandrasekhar, J.; Spitznagel, G. W.; Schleyer, P. V. R. J. Comput. Chem. 1983, 4, 294-301.

66. Lynch, B. J.; Zhao, Y.; Truhlar, D. G. J. Phys. Chem. A 2003, 107, 1384-1388.

67. Frisch, M. J.; Pople, J. A.; Binkley, J. S. J. Chem. Phys. 1984, 80, 3265-3269.

68. Tomasi, J.; Mennucci, B.; Cammi, R. Chem. Rev. 2005, 105, 29993094.

69. Tomasi, J.; Mennucci, B.; Cancès, E. J. Mol. Struct. (THEOCHEM) 1999, 464, 211-226.

70. Marenich, A. V.; Cramer, C. J.; Truhlar, D. G. J. Phys. Chem. B 2009, 113, 6378-6396.

71. Fukui, K. Acc. Chem. Res. 1981, 14, 363-368.

\section{TOC Graphic}

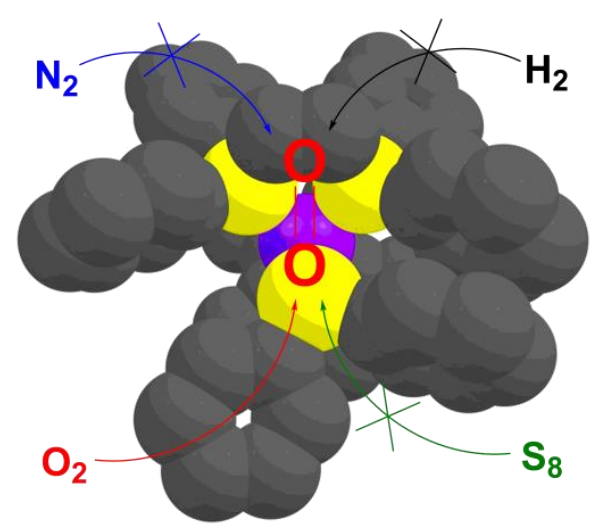

Text: Dioxygen adds selectively at the cleft created by diphenylphosphide and an unsaturated chelating diphosphine on ruthenium to produce an endo epoxide complex. 


\title{
Supporting Information for: Ligand-based Molecular Recognition and Dioxygen Splitting: An Endo Epoxide Ending
}

\author{
Peter E. Sues, Matthew W. Forbes, Alan J. Lough, and Robert H. Morris* \\ Department of Chemistry, University of Toronto, Toronto, Ontario M5S 3H6, Canada
}

Table of Contents:

Selected Bond Lengths and Angles for $\mathbf{2}$ and $\mathbf{5}$

Crystallographic Data Tables for Compounds $\mathbf{2}$ and $\mathbf{5}$

VT NMR Discussion

Electrochemical Discussion 
Table S1. Selected Bond Lengths (๕) and Angles (deg) for 2 and 5.

$\begin{array}{ccc} & \mathbf{2} & \mathbf{5} \\ \mathrm{Ru}(1)-\mathrm{P}(1) & \text { Bond Lengths }(\AA) & \\ \mathrm{Ru}(1)-\mathrm{P}(2) & 2.279(2) & 2.331(4) \\ \mathrm{Ru}(1)-\mathrm{P}(3) & 2.299(2) & 2.277(4) \\ \mathrm{C}(1)-\mathrm{C}(2) & 2.377(2) & 2.376(4) \\ & 1.473(9) & 1.32(2) \\ \mathrm{P}(1)-\mathrm{Ru}(1)-\mathrm{P}(2) & \text { Bond angles }(\mathrm{deg}) & 81.9(2) \\ \mathrm{P}(1)-\mathrm{Ru}(1)-\mathrm{P}(3) & 83.55(6) & 89.9(2) \\ \mathrm{P}(2)-\mathrm{Ru}(1)-\mathrm{P}(3) & 100.64(6) & 89.4(2)\end{array}$


Table S2. Selected Crystal Data, Data Collection, and Refinement Parameters for Compounds 2 and 5.

\begin{tabular}{|c|c|c|}
\hline & 2 & 5 \\
\hline empirical formula & $\mathrm{C}_{48} \mathrm{H}_{47} \mathrm{O}_{2} \mathrm{P}_{3} \mathrm{Ru}$ & $\mathrm{C}_{48} \mathrm{H}_{47} \mathrm{P}_{3} \mathrm{RuS}$ \\
\hline FW & 849.84 & 949.90 \\
\hline lattice type & monoclinic & triclinic \\
\hline space group & $\mathrm{C} 2 / \mathrm{c}$ & $\mathrm{P}-1$ \\
\hline $\mathrm{T}, \mathrm{K}$ & $150(2)$ & $147(2)$ \\
\hline$a, \AA$ & $22.139(4)$ & $10.691(1)$ \\
\hline$b, \AA$ & $11.663(2)$ & $12.001(2)$ \\
\hline$c, \AA$ & $33.324(6)$ & $19.006(2)$ \\
\hline$\alpha, \operatorname{deg}$ & 90 & $73.029(9)$ \\
\hline$\beta, \operatorname{deg}$ & $104.066(6)$ & $88.592(9)$ \\
\hline$\gamma, \operatorname{deg}$ & 90 & $70.042(9)$ \\
\hline $\mathrm{V}, \AA^{3}$ & $8347(3)$ & $2184.8(4)$ \\
\hline $\mathrm{Z}$ & 8 & 2 \\
\hline$\rho_{\text {cald }} / \mathrm{Mg} \mathrm{m}^{-3}$ & 1.353 & 1.292 \\
\hline$\mu(\mathrm{Cu}, \mathrm{K} \alpha) \mathrm{mm}^{-1}$ & 0.529 & 4.619 \\
\hline $\mathrm{F}(000)$ & 3520 & 880 \\
\hline cryst size, $\mathrm{mm}^{3}$ & $0.28 \times 0.20 \times 0.20$ & $0.03 \times 0.02 \times 0.02$ \\
\hline range $\theta$ collected, deg & 1.90 to 27.52 & 4.10 to 66.74 \\
\hline reflns collected/unique & $20144 / 9529$ & $43998 / 7367$ \\
\hline abs cor & \multicolumn{2}{|c|}{ Semi-empirical from equivalents } \\
\hline Max and min transmn coeff. & 0.7456 and 0.7122 & 0.7528 and 0.6458 \\
\hline goodness of fit & 1.040 & 1.147 \\
\hline$R_{1}(\mathrm{I}>2 \sigma(\mathrm{I}))^{a}$ & 0.0350 & 0.0556 \\
\hline$w R_{2}(\text { all data })^{a}$ & 0.0800 & 0.1713 \\
\hline peak and hole, e $\AA^{-3}$ & 0.376 and -0.417 & 1.274 and -2.671 \\
\hline
\end{tabular}




\section{VT NMR Discussion}
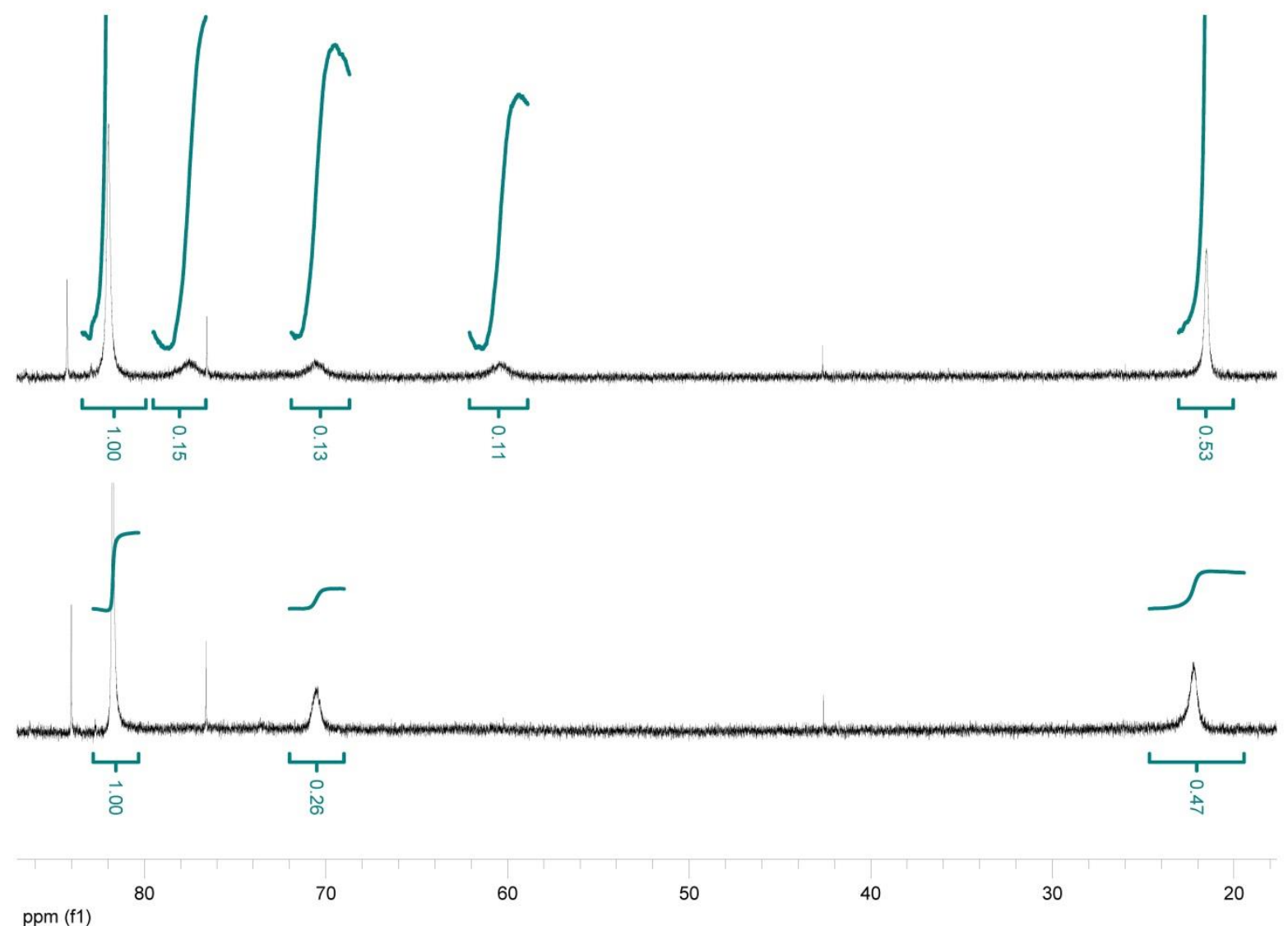

Figure S1. Variable temperature ${ }^{31} \mathrm{P}\left\{{ }^{1} \mathrm{H}\right\}$ NMR $\left(\mathrm{THF}-d_{8}\right)$ spectra of the oxygen activation reaction mixture. The top spectrum was taken at a temperature of $-80^{\circ} \mathrm{C}$, while bottom spectrum was taken at a temperature of $-60^{\circ} \mathrm{C}$.

In the spectrum taken at $-80^{\circ} \mathrm{C}$ the starting material can be seen at 82 and $22 \mathrm{ppm}$, the product epoxide can be seen around $71 \mathrm{ppm}$ (the peaks for the phosphoryl and dppen ligands overlap), and the peroxointermediate can be seen at 78 and $60 \mathrm{ppm}$. Upon heating to $-60^{\circ} \mathrm{C}$ the peroxo-intermediate disappeared, and the integration value for the product increased in a roughly proportional amount to the disappearance 
of the intermediate species (it should be noted ${ }^{31} \mathrm{P}$ NMR integrations are not qualitative, and this is purely a qualitative observation)..

\section{Electrochemical Discussion}
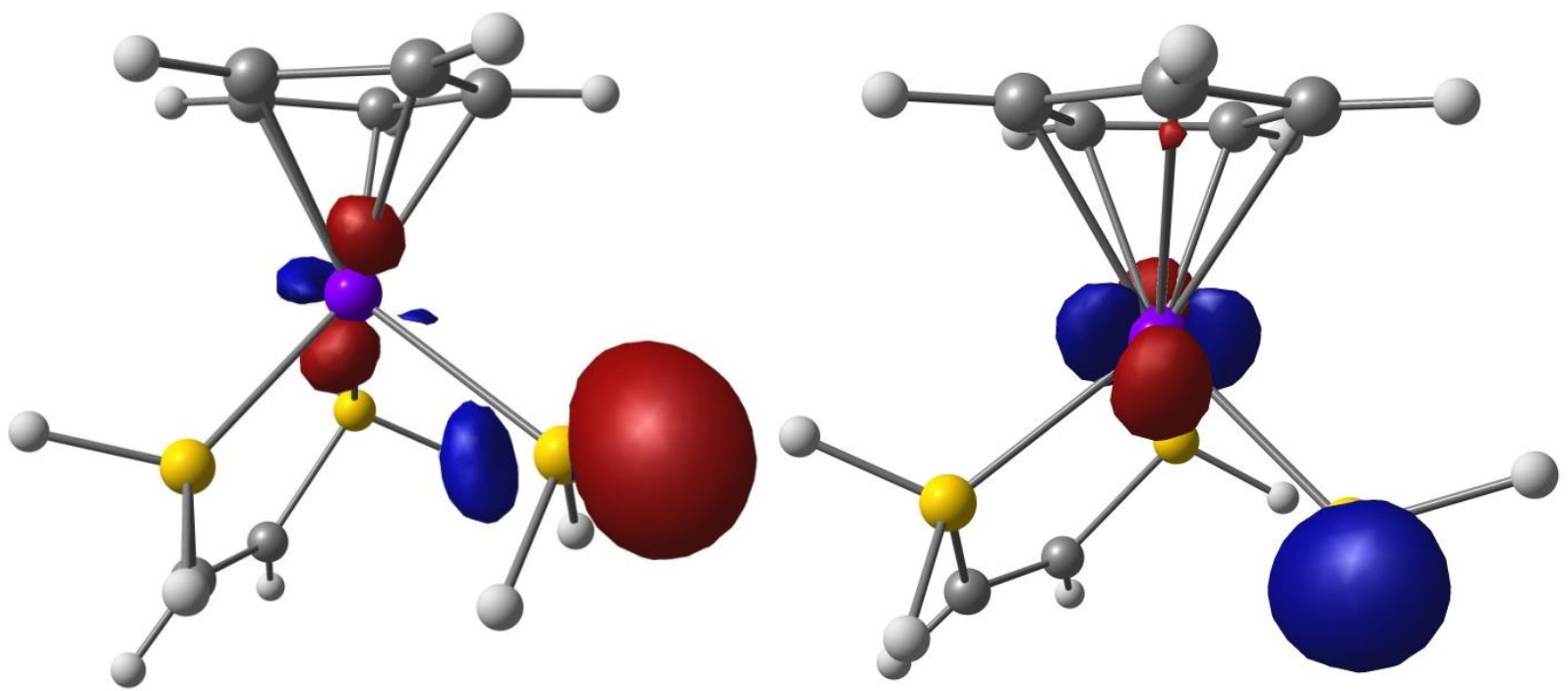

Figure S2. Pictorial representations of the HOMO (left) and SOMO (right) for A and $\mathbf{B}$, respectively.

We have assigned the two quasi-reversible redox couples that were detected with an $\mathrm{E}_{\mathrm{pa}}$ and $\mathrm{E}_{\mathrm{pc}}$ of $0.51 \mathrm{~V}$ and $0.25 \mathrm{~V}$, as well as $-0.48 \mathrm{~V}$ and $-0.73 \mathrm{~V}$ vs. SCE, as metal- and ligand-based, respectively, based on the molecular orbitals of $\mathbf{A}$ and $\mathbf{B}$ generated by our computational studies (Figures 4 and S1). The HOMO of $\mathbf{A}$ has a significant ligand-based contribution, while the SOMO of $\mathbf{B}$ has more metal character, and as such we view the first oxidation of $\mathbf{1}$ as removal of a phosphido electron and the second oxidation as removal of a d-electron. 
Cartesian Coordinates and Free Energies of Optimized Structures.

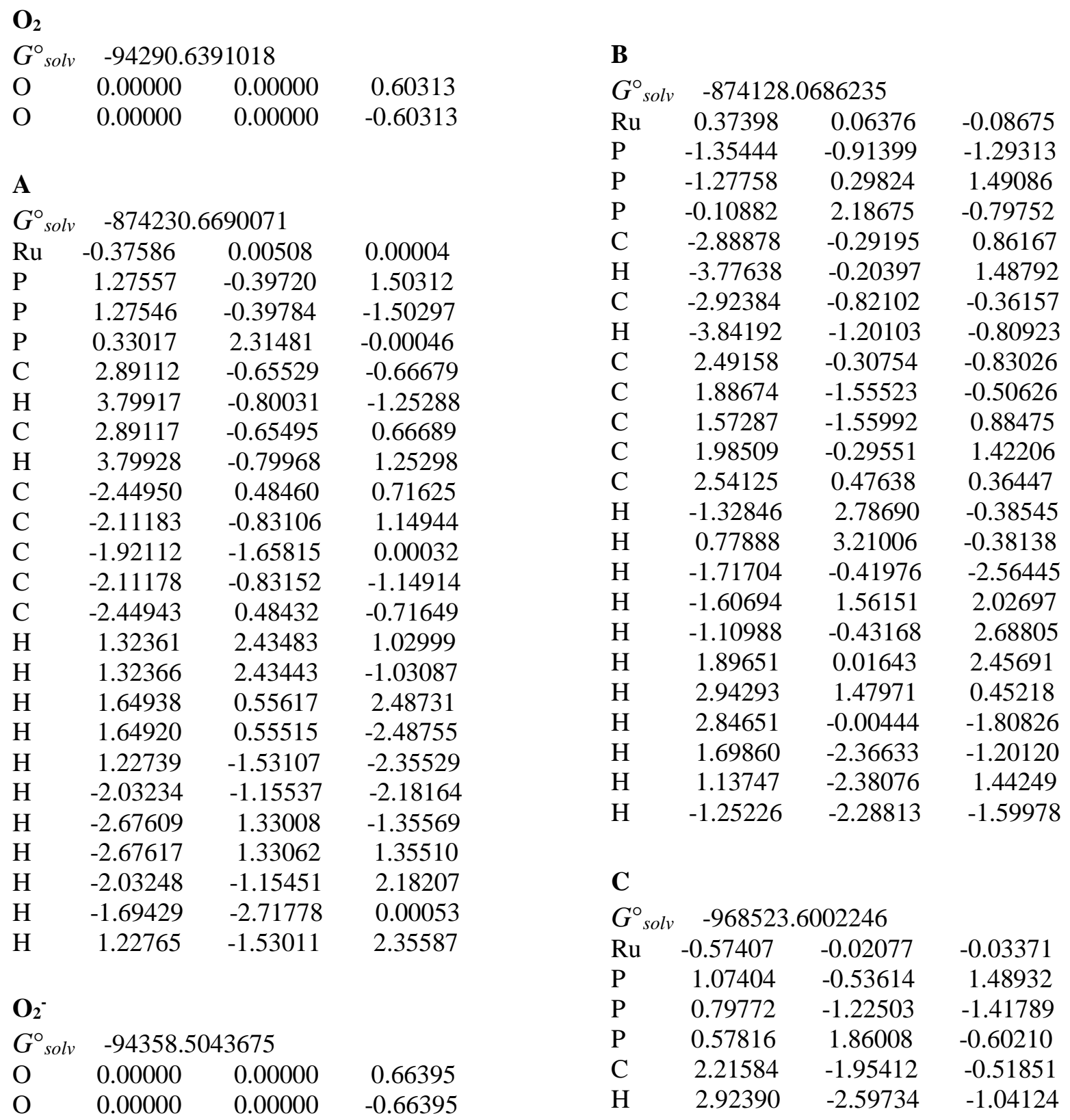




$\begin{array}{lrrr}\mathrm{C} & 2.35843 & -1.61368 & 0.76212 \\ \mathrm{H} & 3.19327 & -1.95847 & 1.37259 \\ \mathrm{C} & -2.43574 & 0.97463 & 0.71775 \\ \mathrm{C} & -2.28840 & -0.27121 & 1.39181 \\ \mathrm{C} & -2.35968 & -1.32454 & 0.43093 \\ \mathrm{C} & -2.54214 & -0.71600 & -0.85198 \\ \mathrm{C} & -2.59676 & 0.69549 & -0.68089 \\ \mathrm{H} & 1.11099 & 1.92665 & -1.91553 \\ \mathrm{H} & -0.25171 & 3.02079 & -0.62709 \\ \mathrm{H} & 1.77148 & 0.38397 & 2.29086 \\ \mathrm{H} & 1.45366 & -0.60023 & -2.50932 \\ \mathrm{H} & 0.26403 & -2.34010 & -2.10771 \\ \mathrm{H} & -2.63244 & -1.24257 & -1.79612 \\ \mathrm{H} & -2.75212 & 1.42835 & -1.46477 \\ \mathrm{H} & -2.44751 & 1.95480 & 1.18084 \\ \mathrm{H} & -2.14160 & -0.39693 & 2.45950 \\ \mathrm{H} & -2.31601 & -2.38733 & 0.63781 \\ \mathrm{H} & 0.59246 & -1.38788 & 2.52291 \\ \mathrm{O} & 2.64783 & 1.20793 & 0.06069 \\ \mathrm{O} & 1.80623 & 2.40246 & 0.30598\end{array}$

$\begin{array}{lrrr}\text { TS } & & & \\ \mathbf{C , D} & & & \\ G^{\circ} \text { solv } & -968553.1942865 & \\ \mathrm{Ru} & -0.61294 & -0.03889 & -0.00519 \\ \mathrm{P} & 0.84512 & -1.08516 & -1.44512 \\ \mathrm{P} & 0.95636 & -0.68120 & 1.54308 \\ \mathrm{P} & 0.65461 & 1.85500 & -0.42818 \\ \mathrm{O} & 2.58934 & 0.56748 & 0.03052 \\ \mathrm{O} & 1.98615 & 2.25133 & 0.34287 \\ \mathrm{C} & 2.49166 & -1.22272 & 0.71189 \\ \mathrm{H} & 3.38907 & -1.42471 & 1.29440 \\ \mathrm{C} & 2.43306 & -1.46778 & -0.62974 \\ \mathrm{H} & 3.29660 & -1.81027 & -1.19626 \\ \mathrm{C} & -2.47016 & -1.31624 & 0.21126 \\ \mathrm{C} & -2.54243 & -0.57644 & -1.01182 \\ \mathrm{C} & -2.55717 & 0.81315 & -0.70199 \\ \mathrm{C} & -2.42488 & -0.36765 & 1.27672 \\ \mathrm{C} & -2.48177 & 0.94562 & 0.72549 \\ \mathrm{H} & -0.13321 & 3.04018 & -0.33377 \\ \mathrm{H} & 0.98988 & 1.95009 & -1.81219 \\ \mathrm{H} & 1.28740 & -0.40252 & -2.60643 \\ \mathrm{H} & 0.46754 & -2.30640 & -2.05755 \\ \mathrm{H} & 0.61350 & -1.76080 & 2.39964 \\ \mathrm{H} & 1.48028 & 0.20041 & 2.51224 \\ \mathrm{H} & -2.47833 & -2.39521 & 0.31065 \\ \mathrm{H} & -2.59042 & -1.00219 & -2.00837 \\ \mathrm{H} & -2.63426 & 1.62569 & -1.41613 \\ \mathrm{H} & -2.49434 & 1.87470 & 1.28394 \\ \mathrm{H} & -2.35967 & -0.60544 & 2.33338\end{array}$

\begin{tabular}{lrrr} 
D & \multicolumn{3}{l}{} \\
G $^{\circ}$ solv & -968622.5312716 & \\
$\mathrm{R}$ & -0.55991 & -0.11643 & -0.02583 \\
$\mathrm{P}$ & 1.02205 & -1.11643 & -1.32428 \\
$\mathrm{P}$ & 1.05655 & -0.13484 & 1.58109 \\
$\mathrm{P}$ & 0.21146 & 1.95812 & -0.71897 \\
$\mathrm{O}$ & 3.16412 & 0.08948 & -0.14344 \\
$\mathrm{O}$ & 0.69507 & 2.99514 & 0.29455 \\
$\mathrm{C}$ & 2.68320 & -0.72444 & 0.91901 \\
$\mathrm{H}$ & 3.44543 & -1.09173 & 1.60940 \\
$\mathrm{C}$ & 2.66398 & -1.20310 & -0.46495 \\
$\mathrm{H}$ & 3.41115 & -1.92479 & -0.80178 \\
$\mathrm{C}$ & -2.60325 & -0.02707 & -0.94464 \\
$\mathrm{C}$ & -2.32473 & -1.39300 & -0.61990 \\
$\mathrm{C}$ & -2.17887 & -1.50959 & 0.78842 \\
$\mathrm{C}$ & -2.34058 & -0.19659 & 1.34301 \\
$\mathrm{C}$ & -2.62066 & 0.70972 & 0.28296 \\
$\mathrm{H}$ & -0.84494 & 2.51447 & -1.51383 \\
$\mathrm{H}$ & 1.17136 & 1.83749 & -1.77876 \\
$\mathrm{H}$ & 1.44982 & -0.56729 & -2.56135 \\
$\mathrm{H}$ & 0.86676 & -2.46341 & -1.72943 \\
$\mathrm{H}$ & 0.90689 & -1.00440 & 2.68832 \\
$\mathrm{H}$ & 1.46982 & 1.03237 & 2.26427 \\
$\mathrm{H}$ & -1.98801 & -2.42088 & 1.34315 \\
$\mathrm{H}$ & -2.24424 & -2.20563 & -1.33456 \\
$\mathrm{H}$ & -2.80698 & 0.36842 & -1.93320 \\
$\mathrm{H}$ & -2.81084 & 1.77251 & 0.38882 \\
$\mathrm{H}$ & -2.28923 & 0.06023 & 2.39555
\end{tabular}


Full Gaussian09 Reference. Gaussian 09, Revision B.01, M. J. Frisch, G. W. Trucks, H. B. Schlegel, G. E. Scuseria, M. A. Robb, J. R. Cheeseman, G. Scalmani, V. Barone, B. Mennucci, G. A. Petersson, H. Nakatsuji, M. Caricato, X. Li, H. P. Hratchian, A. F. Izmaylov, J. Bloino, G. Zheng, J. L. Sonnenberg, M. Hada, M. Ehara, K. Toyota, R. Fukuda, J. Hasegawa, M. Ishida, T. Nakajima, Y. Honda, O. Kitao, H. Nakai, T. Vreven, J. A. Montgomery, Jr., J. E. Peralta, F. Ogliaro, M. Bearpark, J. J. Heyd, E. Brothers, K. N. Kudin, V. N. Staroverov, R. Kobayashi, J. Normand, K. Raghavachari, A. Rendell, J. C. Burant, S. S. Iyengar, J. Tomasi, M. Cossi, N. Rega, J. M. Millam, M. Klene, J. E. Knox, J. B. Cross, V. Bakken, C. Adamo, J. Jaramillo, R. Gomperts, R. E. Stratmann, O. Yazyev, A. J. Austin, R. Cammi, C. Pomelli, J. W. Ochterski, R. L. Martin, K. Morokuma, V. G. Zakrzewski, G. A. Voth, P. Salvador, J. J. Dannenberg, S. Dapprich, A. D. Daniels, Ö. Farkas, J. B. Foresman, J. V. Ortiz, J. Cioslowski, and D. J. Fox, Gaussian, Inc., Wallingford CT, 2010. 